\title{
The Magnitude and Cyclical Behavior of Financial Market Frictions*
}

\author{
Andrew T. Levin Fabio M. Natalucci Egon Zakrajšek ${ }^{\dagger}$ \\ Board of Governors of the Federal Reserve System
}

May 2004

\begin{abstract}
We analyze a new panel data set that includes balance sheet information, measures of expected default risk, and credit spreads on publicly-traded debt for more than 900 firms over the period 1997Q1 through 2003Q3. We obtain precise time-specific estimates of the financial frictions parameter underlying the benchmark financial accelerator model of Bernanke, Gertler, and Gilchrist (1999) and clearly reject the null hypothesis of no credit market imperfections; furthermore, for the expansionary period through mid-2000, these estimates are quite similar to the calibrated values used in previous research. Finally, we find that financial market frictions exhibit strong cyclical pattern, with parameter estimates rising by a factor of two during the latest economic downturn before returning to pre-recession levels in 2003.
\end{abstract}

JEL Classification: D82, E22, G32

KEYWORDS: financial accelerator, bankruptcy costs

${ }^{*}$ We thank David Bowman, Mark Carey, Mark Gertler, Simon Gilchrist, Refet Gürkaynak, and Paul Harrison for helpful comments. Amanda Cox and Jason Grimm provided outstanding research assistance. The views expressed in this paper are solely the responsibility of the authors and should not be interpreted as reflecting the views of the Board of Governors of the Federal Reserve System or of the Federal Reserve System.

${ }^{\dagger}$ Corresponding author: Division of Monetary Affairs, MS-84, Board of Governors of the Federal Reserve System, 20th Street \& Constitution Avenue, NW, Washington D.C., 20551. Tel: (202) 7285864; Email: egon.zakrajsek@frb.gov 


\section{Introduction}

In a world à la Modigliani and Miller (1958) with no financial market imperfections, the capital structure of firms is indeterminate and the aggregate mix of debt versus equity is irrelevant for the evolution of the real economy. Models of economic fluctuations such as IS-LM, real business cycle models, and the canonical new-Keynesian model have relied upon this theorem to justify their abstraction from financing decisions.

Nevertheless, since Fisher's (1933) explanation of the Great Depression ${ }^{1}$, economists have recognised that financial factors can play a crucial role in the amplification and propagation of macroeconomic shocks and in the transmission of monetary policy. As shown in Figure 1, the spread between Baa and Aaa corporate yields - an indicator of the deterioration of financial conditions - widened during most of the NBER-dated recessions since the 1920s. Although this could simply reflect higher expected default costs, it seems unlikely that these costs alone can account for the sharp rise in the spread - given actual defaul rates for Aaa and Baa bonds.

Starting with the seminal work of Bernanke and Gertler (1989), financial market imperfections have been formalized in micro-founded models to explore the role of financial factors during economic downturns. ${ }^{2}$ There is, however, a lack of consensus on the quantitative significance of these frictions for business cycle fluctuations. In the context of dynamic general equilibrium models, financial market frictions have been evaluated solely using calibrated values of the agency cost parameters. The empirical literature, instead, has investigated the extent to which financial balance sheet variables influence investment, production, and employment decisions of firms. Though not without controversy, the general finding is that the real decisions of firms that are most likely to be facing severe informational problems in credit markets

\footnotetext{
${ }^{1}$ Fisher (1933) argued that the deterioration of borrowers' balance sheets stemming from "debt deflation" contributed importantly to the severity and persistence of the Great Depression. More recent work on that era by Bernanke (2000) and Christiano, Motto, and Rostagno (2004) has identified a host of other financial factors that reinforced the contraction phase of the early 1930s.

${ }^{2}$ Informational asymmetries between borrowers and lenders have been introduced under various guises into general equilibrium models by Carlstrom and Fuerst (1997), Kiyotaki and Moore (1997), Bernanke, Gertler, and Gilchrist (1999), and Cooley, Marimon, and Quadrini (2004). Implications of financial market frictions for the transmission of monetary policy are discussed by Bernanke and Gertler (1995). Following the 1997 Asian financial crisis, a number of economists started considering implications of credit market imperfections in open-economy settings; see, for example, Krugman (1999), Aghion, Bacchetta, and Banerjee (2000), Cespedes, Chang, and Velasco (2000), Caballero and Krishnamurthy (2000), and Gertler, Gilchrist, and Natalucci (2003).
} 
Figure 1: Spread between Baa and Aaa Corporate Yields

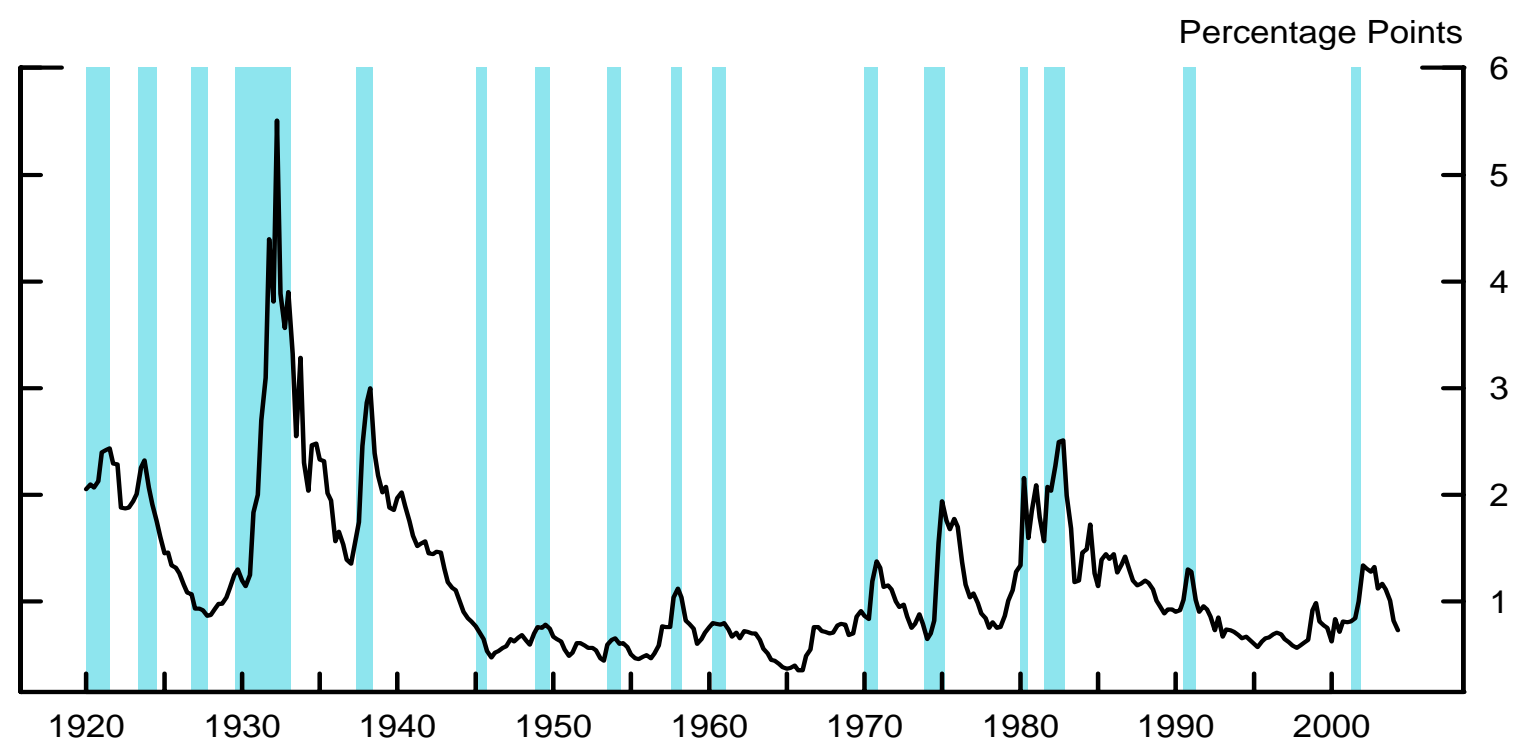

Note. Shaded vertical bars denote NBER-dated recessions.

are excessively sensitive to movements in balance sheet variables like cash flow and net worth. ${ }^{3}$ These results, although generally consistent with the existence of credit market imperfections, do not provide direct evidence of the magnitude of agency costs, leaving the question of the empirical relevance of financial market imperfections generally unanswered.

In this paper, we use a new firm-level dataset to quantify the magnitude of financial market fricions. Our panel includes more than 900 large firms over the period 1997Q1 through 2003Q3 and covers a significant portion of the nonfarm nonfinancial corporate sector. The novel feature of our dataset is that it links balance sheet information to credit spreads on publicly-traded corporate debt and to market-based

\footnotetext{
${ }^{3}$ This approach has been motivated by the failure of the Q-model of investment to account adequately for firm-level investment dynamics, a result often attributed to the misspecification caused by the effects of credit market imperfections. The empirical strategy typically relies on an a priori chosen proxy for the severity of informational problems in credit markets (e.g., firm size, the presence of bond rating, etc.) to classify firms into "credit constrained" and "credit unconstrained" groups. Under the null hypothesis of no credit market frictions, cash flow and other balance sheet variables should not have a differential effect on investment spending of the two sets of firms; see Hubbard (1998) for a comprehensive of review of this literature. An alternative interpretation of the role of cash flow in investment equations that does not rely on credit market frictions is provided by Kaplan and Zingales (1997) and Cummins, Hassett, and Oliner (1999).
} 
measures of expected default risk. Using non-linear least squares, we estimate the structural parameters of the contracting problem between lender and entrepreneur of the benchmark financial accelerator model of Bernanke, Gertler, and Gilchrist (1999) (BGG hereafter).

We obtain precise time-specific estimates of the bankruptcy cost parameter, which enable us to clearly reject the null hypothesis of frictionless financial markets. Furthermore, for the expansionary period through mid-2000 our estimates are quite similar to the calibrated values used in previous research. We also find that the degree of financial market frictions exhibits strong cyclicality. The parameter estimate of bankruptcy costs, in fact, increases by a factor of two during the latest economic downturn before returning to pre-recession levels in early 2003. Finally, we show that the model-implied (unobservable) external finance premium was close to zero until the end of 1999 but rose sharply afterwards, providing an important explanation for the sharp drop in capital spending during the latest economic contraction.

The remainder of the paper is organized as follows. Section 2 specifies the microeconomic debt-contracting framework and examines its comparative statics. Section 3 provides an overview of the data, while Section 4 describes the estimation methodology. Section 5 presents the empirical results, and Section 6 concludes. 


\section{The Theoretical Framework}

In an influential recent paper, BGG embed the costly-state verification (CSV) debt contracting problem of Townsend (1979) and Gale and Hellwig (1985) into a dynamic stochastic general equilibrium model with money and sticky prices. In the CSV framework, there are "bad" states of the world in which it is optimal for a firm to default on its debt obligations. Agency costs arise because limited liability creates an incentive for a firm to default in "good" states. To ascertain whether the true state of the world warrants default, a lender has to pay a cost. Because borrowers have insufficient wealth with which to finance their investment projects, a lender will, in equilibrium, demand an external finance premium (cost of external funds less the opportunity cost of internal funds) in order to be compensated for this verification cost.

In general equilibrium, the CSV framework gives rise to a financial accelerator. The key factor in the amplification mechanism is the negative relationship between the leverage of borrowers (the ratio of debt to net worth) and the external finance premium. Reflecting shocks to return to capital and to ex post real borrowing costs, net worth moves procyclically, causing countercyclical swings in the external finance premium. Because of these endogenous fluctuations in net worth, movements in the external finance premium are highly persistent, and fluctuations of macroeconomic variables are magnified and propagated through the economy. In the remainder of this section, we present the formal details of the debt contracting problem and examine its comparative statics.

\subsection{The Debt Contracting Problem}

At the end of period $t-1$, an entrepreneur who manages firm $i$ purchases (homogeneous) capital to be used in production during period $t$. Ex ante, the revenue expected from the investment project is given by $R_{t}^{k} Q_{t-1} K_{i t}$, where $K_{i t}$ is the quantity of capital that the entrepreneur purchases at unit price $Q_{t-1}$ (measured at the end of period $t-1$ relative to the price of the final good), and $R_{t}^{k}$ is the aggregate gross rate of return on capital investment. ${ }^{4}$

\footnotetext{
${ }^{4}$ Following the BGG convention, the time subscript on capital denotes the period in which the capital is actually used. We assume that when making the investment decision, the entrepreneur takes $Q_{t-1}$ and $R_{t}^{k}$ as given. In general equilibrium, of course, both the price and the return on capital are endogenous.
} 
Realized revenue in period $t$ is given by $\omega_{i t} R_{t}^{k} Q_{t-1} K_{i t}$, where $\omega_{i t} \in \mathbb{R}^{+}$is an i.i.d. (across firms and time) productivity disturbance with the probability density function $f(\omega)$ and $E\left[\omega_{i t}\right]=1$ for all $t$. Because the entrepreneur has insufficient net worth to finance the entire capital investment, he must obtain a loan from a risk-neutral financial intermediary. Letting $N_{i t-1}$ denote the entrepreneur's net worth at the end of period $t-1$, he borrows $B_{i t-1}$ to purchase the requisite amount of capital:

$$
B_{i t-1}+N_{i t-1}=Q_{t-1} K_{i t}
$$

The entrepreneur's profit is then given by

$$
\omega_{i t} R_{t}^{k} Q_{t} K_{i t}-R_{i t}^{b} B_{i t-1}
$$

where $R_{i t}^{b}$ is the contractual gross interest rate paid on the loan amount $B_{i t-1}$.

To fund loans, the intermediary raises funds at the risk-free gross interest rate $R_{t} \leq R_{t}^{k}$. If the lender had complete information about the idiosyncratic shock $\omega_{i t}$, arbitrage would ensure that in equilibrium $R_{t}^{k}=R_{t}$. The lender, however, can only observe $\omega_{i t}$ by paying a "monitoring cost," assumed to be proportional to the realized revenue from the project. In particular, if the borrower claims an adverse productivity shock and defaults on his debt obligations, the lender, after verifying the entrepreneur's claim, receives residual revenue equal to

$$
(1-\mu) \omega_{i t} R_{t}^{k} Q_{t-1} K_{i t}
$$

where $0<\mu<1$ measures costs associated with bankruptcy proceedings. ${ }^{5}$

The presence of bankruptcy costs and asymmetric information about the firmspecific productivity shock creates an incentive for the entrepreneur to claim default in situations when the realized productivity is high. Reflecting these agency problems, the incentive-compatible debt contract between the lender and entrepreneur stipulates a productivity threshold such that if the realized productivity is above the threshold, the borrower repays the loan and keeps the remainder of the revenue from the project. If, however, the realized productivity falls below the specified thresh-

\footnotetext{
${ }^{5}$ As argued by Smith and Strömberg (2003), the main purpose of corporate bankruptcy law is to mitigate bargaining frictions when a firm is in financial distress. These frictions necessarily entail costs to the lender that include, but are not limited to, the verification of assets and liabilities, the protection of assets during bargaining among claimants, and costs of liquidating the firm's assets.
} 
old, the entrepreneur will be faced with negative profits and will declare bankruptcy, leaving the proceeds of the project - net of bankruptcy costs - to the lender.

The default productivity threshold in the debt contract $\bar{\omega}_{i t}$ is defined by

$$
R_{i t}^{b} B_{i t-1}=\bar{\omega}_{i t} R_{t}^{k} Q_{t-1} K_{i t}
$$

and implicitly determines the contractual interest rate $R_{i t}^{b}$ :

$$
R_{i t}^{b}=\bar{\omega}_{i t}\left[1+\frac{B_{i t-1}}{N_{i t-1}}\right] R_{t}^{k}
$$

Thus, under the incentive-compatible debt contract, the entrepreneur's expected profit will be given by $\psi\left(\bar{\omega}_{i t}\right) R_{t}^{k} Q_{t-1} K_{i t}$, where

$$
\psi\left(\bar{\omega}_{i t}\right)=\int_{\bar{\omega}_{i t}}^{\infty}\left(\omega_{i t}-\bar{\omega}_{i t}\right) f(\omega) d \omega
$$

Note that if $\omega_{i t}<\bar{\omega}_{i t}$, the entrepreneur declares bankruptcy and simply walks away from the project with nothing. The expected return to the lender under such a contract can be expressed as $\xi\left(\bar{\omega}_{i t} ; \mu\right) R_{t}^{k} Q_{t-1} K_{i t}$, where

$$
\xi\left(\bar{\omega}_{i t} ; \mu\right)=(1-\mu) \int_{0}^{\bar{\omega}_{i t}} \omega_{i t} f(\omega) d \omega+\bar{\omega}_{i t} \int_{\bar{\omega}_{i t}}^{\infty} f(\omega) d \omega .
$$

In equilibrium, therefore, the optimal debt contract negotiated at the end of period $t-1$ specifies the amount $B_{i t-1}$ that the entrepreneur can borrow along with the default productivity threshold $\bar{\omega}_{i t}$, so as to maximize the expected return of the investment project, subject to the constraint that the lender earns the risk-free rate $R_{t}: 6$

$$
\begin{array}{cl}
\max _{B_{i t-1}, \bar{\omega}_{i t}} & \psi\left(\bar{\omega}_{i t}\right) R_{t}^{k}\left(B_{i t-1}+N_{i t-1}\right) \\
\text { s.t. } & \\
& \xi\left(\bar{\omega}_{i t} ; \mu\right) R_{t}^{k}\left(B_{i t-1}+N_{i t-1}\right)=R_{t} B_{i t-1} .
\end{array}
$$

\footnotetext{
${ }^{6}$ See BGG for additional technical details that guarantee a solution without credit rationing and that ensure entrepreneur's participation in the project. We checked our numerical results to make sure that they are consistent with all the assumptions of the BGG framework.
} 
Rearranging the first-order conditions yields,

$$
\begin{aligned}
\frac{R_{t}^{k}}{R_{t}} & =\frac{\psi^{\prime}\left(\bar{\omega}_{i t}\right)}{\psi\left(\bar{\omega}_{i t}\right) \xi^{\prime}\left(\bar{\omega}_{i t} ; \mu\right)-\psi^{\prime}\left(\bar{\omega}_{i t}\right) \xi\left(\bar{\omega}_{i t} ; \mu\right)} ; \\
\frac{B_{i t-1}}{N_{i t-1}} & =-\frac{\psi^{\prime}\left(\bar{\omega}_{i t}\right) \xi\left(\bar{\omega}_{i t} ; \mu\right)}{\psi\left(\bar{\omega}_{i t}\right) \xi^{\prime}\left(\bar{\omega}_{i t} ; \mu\right)} .
\end{aligned}
$$

Given the aggregate rate of return on capital $R_{t}^{k}$ and the risk-free rate $R_{t}$, equation 4 determines the default productivity threshold $\bar{\omega}_{i t}$ that characterizes the debt contract. Equation 5, in turn, determines the firm's leverage ratio $\frac{B_{i t-1}}{N_{i t-1}}$. Together, the optimal debt contract generates a schedule relating the firm's leverage ratio to the external finance premium, $\frac{R_{t}^{k}}{R_{t}}$. Because the external finance premium is unobservable, we can use the equation 1 -which defines the contractual rate $R_{i t}^{b}$ - to obtain a relationship linking the observable credit spread for firm $i, \frac{R_{i t}^{b}}{R_{t}}$, to the firm's leverage $\frac{B_{i t-1}}{N_{i t-1}}$, the default productivity threshold $\bar{\omega}_{i t}$, and the external finance premium $\frac{R_{t}^{k}}{R_{t}}$ :

$$
\frac{R_{i t}^{b}}{R_{t}}=\bar{\omega}_{i t}\left(1+\frac{B_{i t-1}}{N_{i t-1}}\right) \frac{R_{t}^{k}}{R_{t}} .
$$

It is worth noting that even in the frictionless case, in which $\mu=0$ and $R_{t}^{k} / R_{t}=1$, equation 6 implies a positive spread between the contractual rate $R_{i t}^{b}$ and the risk-free rate $R_{t}$. This spread exists to compensate the lender for the fact that a certain fraction of firms will inevitably default on their debt obligations, and the equilibrium stipulates that the lender earns the risk-free rate of return. In the presence of bankruptcy costs, credit spreads also include an external finance premium component. However, movements in the external finance premium do not lead to one-to-one movements in the credit spread, because when $\mu>0$, the first-order conditions 4 and 5 imply endogenous changes in the default productivity threshold and leverage.

\subsection{Comparative Statics}

To gain a better insight into how various model-implied relationships vary with changes in the key structural parameters - namely the degree of financial frictions $\mu$ and the variance of the idiosyncratic productivity shock $\sigma^{2}$-we turn to comparative statics. Following BGG, we assume that the productivity disturbance $\omega_{i t}$ is 
distributed log normally as

$$
\ln \omega_{i t} \sim \mathrm{N}\left(-0.5 \sigma^{2}, \sigma^{2}\right)
$$

This assumption yields the following expressions for $\psi(\cdot ; \sigma)$ and $\xi(\cdot ; \sigma, \mu)$ :

$$
\begin{aligned}
\psi\left(\bar{\omega}_{i t} ; \sigma\right) & =1-\Phi\left(\frac{\ln \bar{\omega}_{i t}-0.5 \sigma^{2}}{\sigma}\right)-\bar{\omega}_{i t}\left[1-\Phi\left(\frac{\ln \bar{\omega}_{i t}+0.5 \sigma^{2}}{\sigma}\right)\right] ; \\
\xi\left(\bar{\omega}_{i t} ; \sigma, \mu\right) & =1-\psi\left(\bar{\omega}_{i t}\right)-\mu \Phi\left(\frac{\ln \bar{\omega}_{i t}-0.5 \sigma^{2}}{\sigma}\right),
\end{aligned}
$$

where $\Phi(\cdot)$ denotes the standard normal cumulative distribution function.

Figure 2 considers the implications of varying the magnitude of financial market frictions $(\mu=0,0.12,0.24,0.36)$, assuming a constant standard deviation of idiosyncratic productivity shocks $(\sigma=0.28) .{ }^{7}$ As seen in the top left panel, the default productivity threshold $\bar{\omega}$ is relatively invariant with respect to $\mu$ over a considerable range of leverage. It is only for highly leveraged borrowers that increases in bankruptcy costs generate significant differences in the default threshold. In this case, an increase in $\mu$ causes a decrease in $\bar{\omega}$, because the optimal contract between the lender and the entrepreneur stipulates a lower default threshold in order to reduce the incidence of increasingly costly default. Despite the lower probability of default (top right panel), the external finance premium schedule (bottom left panel) steepens considerably, and the lender demands a wider credit spread (bottom right panel): Intuitively, a higher external finance premium and credit spread at a given leverage reflect greater bankruptcy costs in the event of default.

Note that the default productivity threshold $\bar{\omega}$ is at the highest level (for any leverage) when $\mu=0$. The frictionless case generates the highest and the steepest default probability schedule, but because there is no dead-weight loss associated with bankruptcy, the external finance premium is zero. The positive relationship between leverage and credit spreads when $\mu=0$ reflects solely a higher probability of default that comes with greater leverage, an implication, in turn, of an upward-sloping $\bar{\omega}-$ leverage schedule.

The effects of changes in the volatility of idiosyncratic risk $(\sigma=0.14,0.28,0.42)$

\footnotetext{
${ }^{7}$ The calibration used by BGG corresponds to $\mu=0.12$ and $\sigma=0.28$. When calculating the annualized external finance premium and the annualized credit spread, we set the risk-free rate equal to three percent.
} 
Figure 2

\section{Changes in Bankruptcy Costs}

Default Productivity Threshold

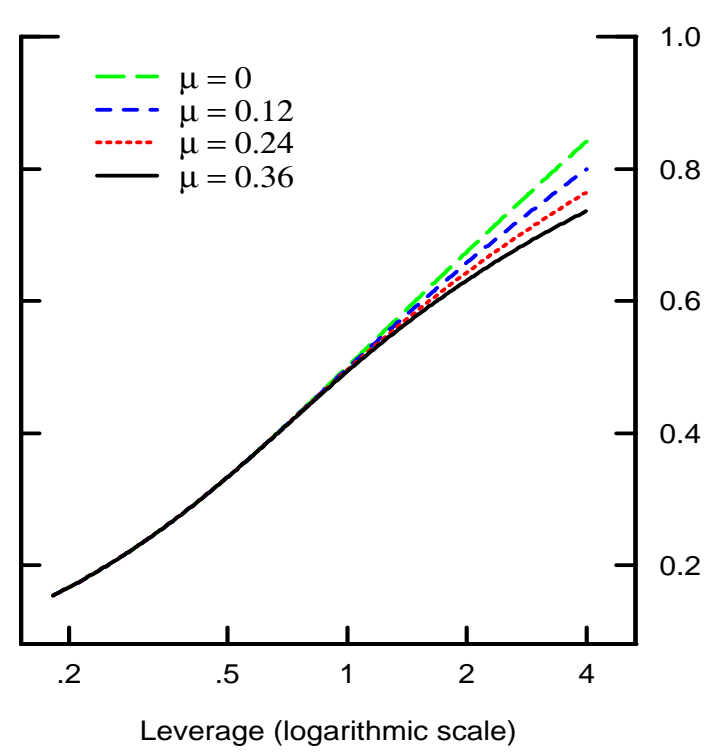

External Finance Premium

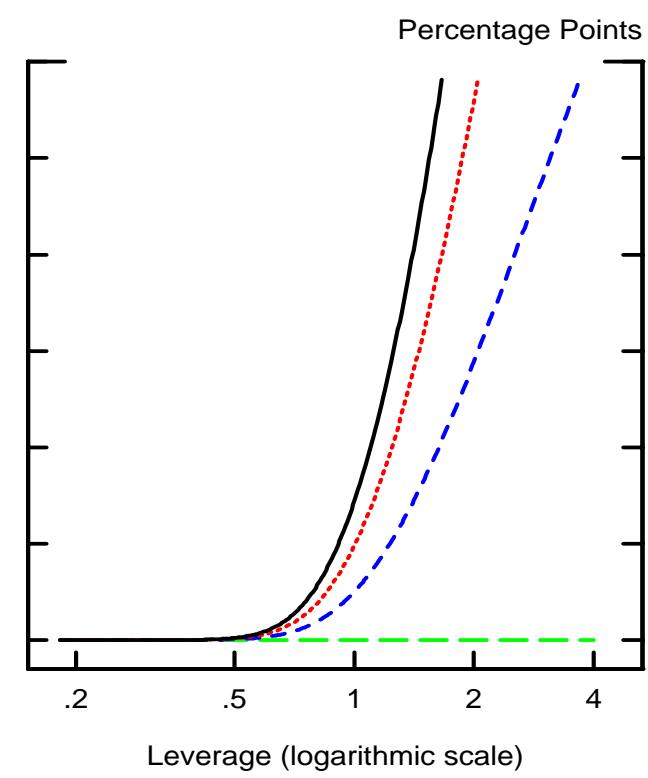

Probability of Default

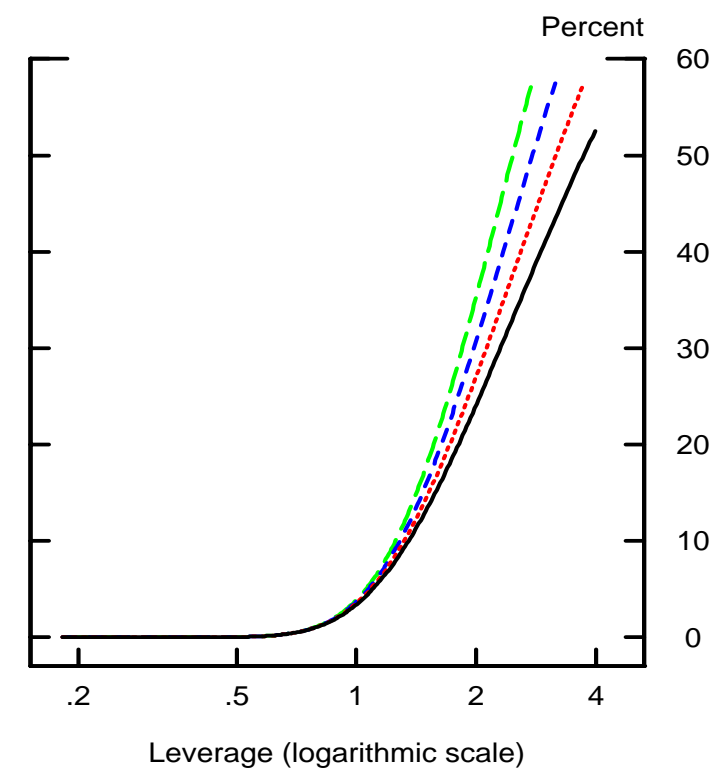

Credit Spread

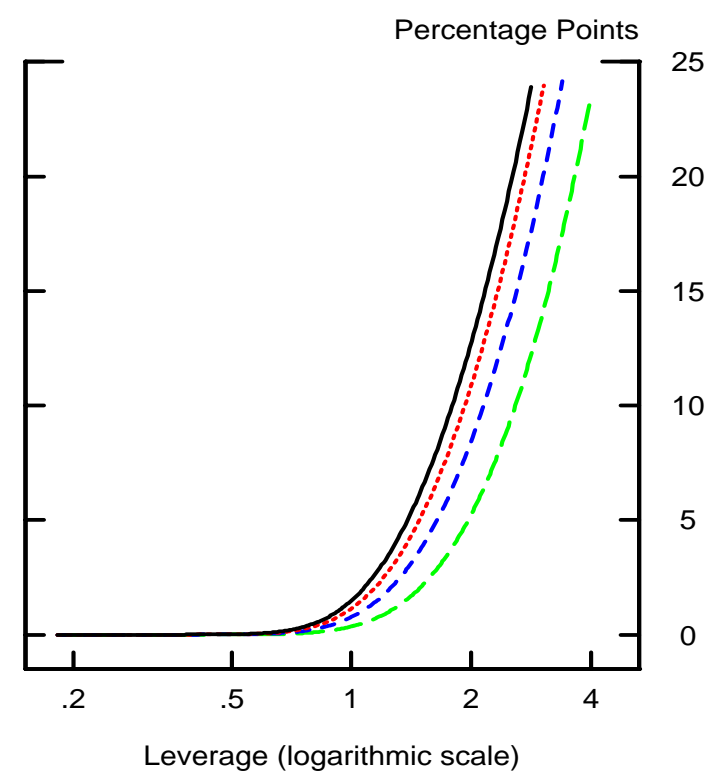

Note. Standard deviation of the idiosyncratic productivity shock $(\sigma)$ is set equal to 0.28 . The external finance premium and the credit spread are measured relative to a risk-free rate of 3 percent. 
while holding bankruptcy costs constant $(\mu=0.12)$ are shown in Figure 3. As $\sigma$ increases and riskier investment projects are being financed, the $\bar{\omega}$-leverage schedule shifts up (top left panel). Although increases in the default threshold are very small for most reasonable values of leverage, they translate, for a given leverage, into a considerably higher likelihood of default (top right panel). The resulting jump in expected bankruptcies accordingly causes a significant upward shift in both the external finance premium and the credit spread schedules over a much wider range of leverage (bottom panels).

The size of the bankruptcy parameter $\mu$, as well as that of $\sigma$, is an open empirical question. Moreover, the potential variability of these two parameters over the course of the business cycle has important implications for the behavior of the external finance premium, a key unobservable variable determining the magnitude of the financial accelerator. To shed light on these questions, we constructed a new dataset linking firm-level balance sheet variables to credit spreads and market-based measures of expected default risk, which allows us to estimate directly the volatility of idiosyncratic risk and the magnitude of bankruptcy costs implied by the BGG debt-contracting problem for the 1997-2003 period. Estimates of these structural parameters, in turn, permit us to examine the behavior of the model-implied external finance premium during the most recent economic downturn. 
Figure 3

\section{Changes in Volatility of Idiosyncratic Risk}

Default Productivity Threshold

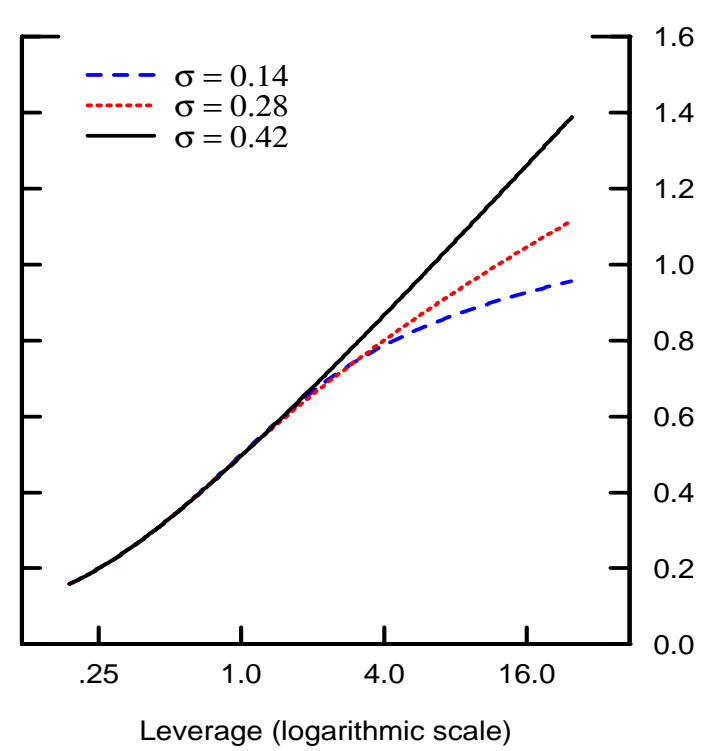

External Finance Premium

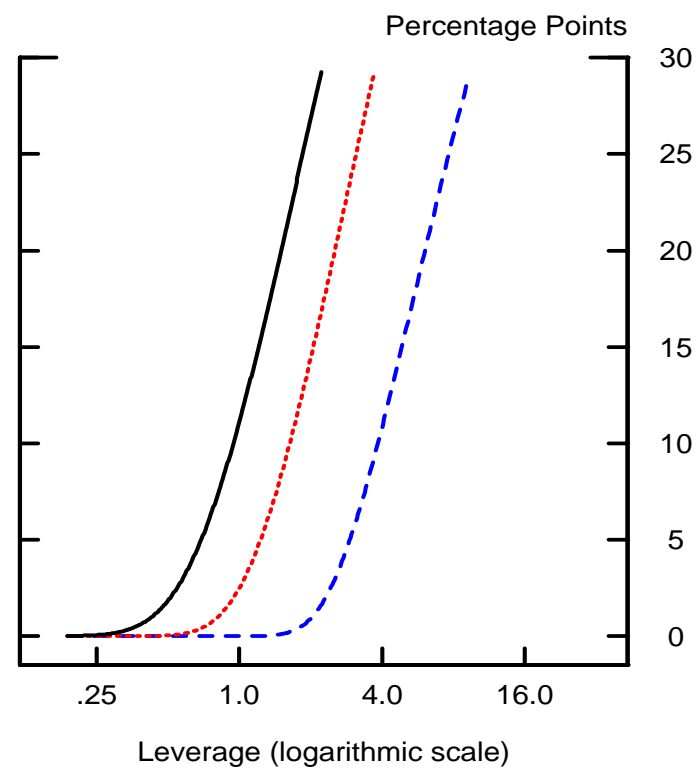

Probability of Default

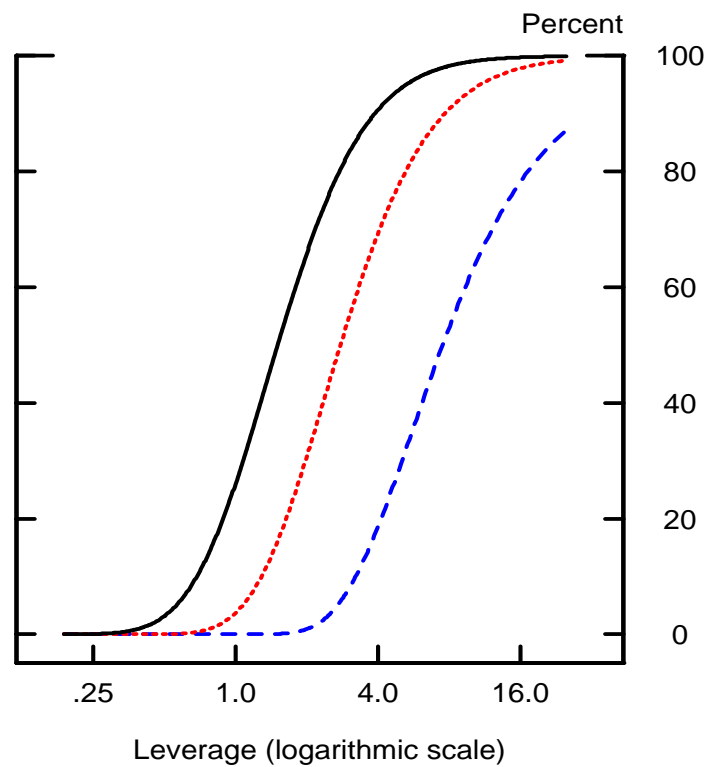

Credit Spread

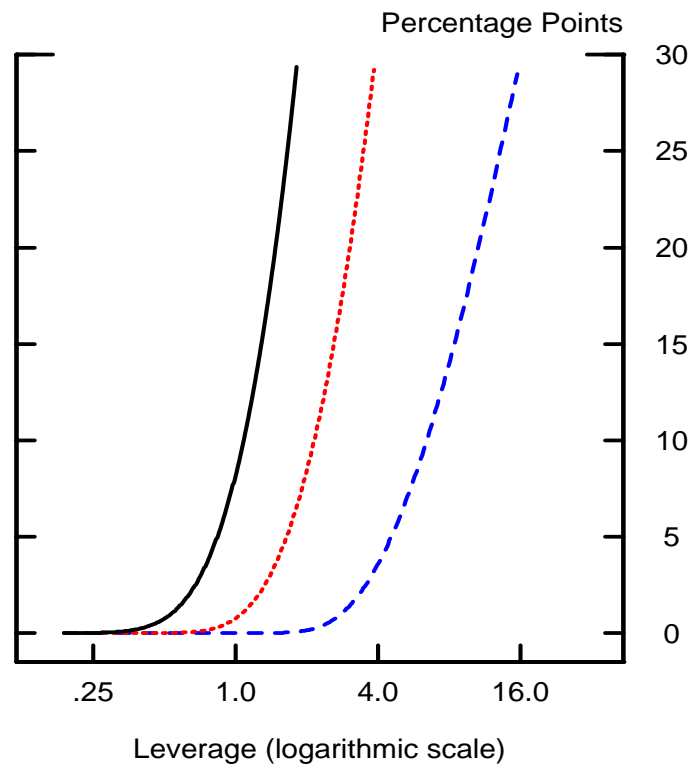

Note. Bankruptcy cost parameter $(\mu)$ is set equal to 0.12 . The external finance premium and the credit spread are measured relative to a risk-free rate of 3 percent. 


\section{Data Description}

Our dataset is an unbalanced quarterly panel for 918 publicly-traded Compustat firms in the U.S. nonfarm nonfinancial corporate sector from 1997Q1 to 2003Q3 (27 quarters). ${ }^{8}$ The distinguishing feature of firms in our sample is that a significant part of their long-term debt is in form of bonds that are actively traded in the secondary market. For these firms, we have linked market prices of their outstanding securities and market-based measures of default risks to Compustat's balance sheet statements. We now turn to the construction of our key variables: leverage, credit spreads, and expected probabilities of default.

\subsection{Sources and Methods}

Leverage. Our measure of the firm's leverage is constructed using Compustat balance sheet information. Leverage is defined as the ratio of the book value of long-term debt (all debt obligations due in more than one year from the firm's balance sheet at the end of the quarter) to the market-value of common equity. ${ }^{9}$ We use the book value of debt, as opposed to the market value, because the book value is the amount that the firm must repay. Market capitalization is computed by multiplying the number of common shares outstanding by the closing stock price, both measured at the end of the quarter.

Credit spreads. Daily market prices of corporate bonds were obtained from the Merrill Lynch database that includes prices of dollar-denominated corporate bonds publicly issued in the U.S. bond market. ${ }^{10}$ Qualifying securities must have at least one year remaining term-to-maturity, a fixed coupon schedule, and a minimum amount outstanding of $\$ 100$ million for below investment-grade and $\$ 150$ million for investmentgrade issuers.

To calculate an overall credit spread on the firm's outstanding bonds, we matched the daily effective yield on each individual security issued by the firm to the estimated yield on the Treasury coupon security of the same maturity. Treasury yields

\footnotetext{
${ }^{8}$ The membership in our panel is limited to firms that reported at least 4 consecutive quarters of income and balance sheet data.

${ }^{9}$ We restrict the numerator of the leverage ratio to long-term debt because our secondary-market prices pertain to long-term corporate securities. In addition, firms often maintain a stock of liquid assets to cover their short-term liabilities.

${ }^{10}$ The Merrill Lynch individual security prices are available starting in 1997.
} 
were taken from a smoothed yield curve estimated on a large sample of off-the-run Treasury coupon securities using the technique proposed by Svensson (1994). ${ }^{11}$ The resulting spread between corporate and Treasury securities, however, is distorted by the differential tax treatment of corporate and government debt-corporate bond coupons are subject to taxes at the state level whereas Treasury coupons are not. Because investors compare returns across instruments on an after-tax basis, yields on corporate bonds will be systematically higher than yields on government securities to compensate for the payment of state taxes. Indeed, Elton et al. (2001) estimate that, on average, these tax factors can account for as much as 20 percent of corporate credit spreads.

We used the method proposed by Cooper and Davydenko (2002) to estimate the distortionary effect of the state-level taxation on corporate bond spreads. According to Elton et al. (2001), the relevant tax rate for the tax-adjusted spread between corporate and government securities is given by $\tau=t_{s}\left(1-t_{g}\right)$, where $t_{s}$ and $t_{g}$ are the state and the federal tax rates, respectively. As suggested, we set $\tau$ equal to $4.875 \%$ and compute for each corporate security the portion of the spread due to taxes according to

$$
\Delta y^{\tau}=\frac{1}{t_{M}} \ln \left[\frac{1-\tau}{1-\tau \exp \left(-r_{t_{M}} t_{M}\right)}\right],
$$

where $t_{M}$ is the corporate security's maturity and $r_{t_{M}}$ is the corresponding Treasury coupon yield (see Cooper and Davydenko (2002) for further details). To calculate an overall firm-specific credit spread, we averaged the tax-adjusted spreads on the firm's outstanding bonds, using the product of market values of bonds and their effective durations as weights. ${ }^{12}$ We matched the firm-specific daily spreads to quarterly balance sheet information by averaging the daily spreads over the first month of the quarter. ${ }^{13}$

\footnotetext{
${ }^{11}$ On-the-run securities were excluded from the sample because yields on those securities are strongly influenced by liquidity premiums, which can affect the shape of the estimated yield curve and, moreover, can shift the curve around the auction cycle.

${ }^{12}$ The use of the dollar duration of bonds as a weight in computing the yield on a portfolio of bonds represents a first-order Taylor series approximation to the portfolio yield; see Choi and Park (2002) for details. Our results were virtually identical when portfolio spreads were averaged using market values of bonds as weights only.

${ }^{13}$ That is, credit spreads matched to any first quarter of balance sheet data are averages of the daily spreads in January, spreads during the second quarter are averages of the daily spreads during April, and so on. We also converted daily spreads to a quarterly frequency by averaging over the entire quarter. All of the results reported in this paper were robust to this alternative timing assumption.
} 
Default probabilities. Our measure of the probability that a firm in our sample will default within a certain period of time comes from the Moody's $\mid \mathrm{K} \cdot \mathrm{M} \cdot \mathrm{V}$ Corporation (MKMV). The theoretical underpinnings to these probabilities of default are provided by the seminal work of Merton $(1973,1974)$. According to this option-theoretic approach, the probability that a firm will default on its debt obligations at any point in the future is determined by three major factors: the market value of the firm's assets, the standard deviation of the stochastic process for the market value of assets (i.e., asset volatility), and the firm's leverage. These three factors are combined into a single measure of default risk called distance to default, defined as

$$
\left[\begin{array}{c}
\text { Distance } \\
\text { to Default }
\end{array}\right]=\frac{\left[\begin{array}{c}
\text { Mkt. Value } \\
\text { of Assets }
\end{array}\right]-\left[\begin{array}{c}
\text { Default } \\
\text { Point }
\end{array}\right]}{\left[\begin{array}{c}
\text { Mkt. Value } \\
\text { of Assets }
\end{array}\right] \times\left[\begin{array}{c}
\text { Asset } \\
\text { Volatility }
\end{array}\right]}
$$

In theory, the default point should equal to the book value of total liabilities, implying that the distance to default compares the net worth of the firm with the size of a one-standard-deviation move in the firm's asset value. ${ }^{14}$ The market value of assets and the volatility of assets, however, are not directly observable, so they have to be computed in order to calculate the distance to default. Assuming that the firm's assets are traded, the market value of the firm's equity can be viewed as a call option on the firm's assets with the strike price equal to the current book value of the firm's total debt. ${ }^{15}$ Using this insight, MKMV "backs out" the market value and the volatility of assets from a proprietary variant of the Black-Scholes-Merton option pricing model, employing the observed book value of liabilities and the market value of equity as inputs; see Crosbie and Bohn (2003) for details.

In the final step, MKMV transforms the distance to default into an expected probability of default - the so-called expected default frequency (EDF) - using an empirical distribution of actual defaults. Specifically, MKMV estimates a mapping relating the likelihood of default over a particular horizon to various levels of distance to default, employing an extensive proprietary database of historical defaults and

\footnotetext{
${ }^{14}$ Empirically, however, MKMV has found that most defaults occur when the market value of the firm's assets drops to the value equal to the sum of the firm's current liabilities and one-half of long-term liabilities (i.e., Default Point $=$ Current Liabilities $+0.5 \times$ Long-Term Liabilities), and the default point is calibrated accordingly.

${ }^{15}$ The assumption that all of the firm's assets are traded is clearly inappropriate in most cases. Nevertheless, as shown by Ericsson and Reneby (1999), this approach is still valid provided that at least one of the firm's securities (e.g., equity) is traded.
} 
bankruptcies in the United States. ${ }^{16}$ In our case, these EDFs are calculated monthly and measure the probability that a firm will default on its debt obligations over the next 12 months. We used EDFs as of the last month of the quarter when merging MKMV data to the quarterly Compustat balance sheet variables.

It should be noted that MKMV does not disclose how the mapping between the distance to default and the EDF is computed. However, these timely, forward-looking measures of default risk are widely used by financial market participants when assessing credit risk. One clear advantage of EDFs over the traditional measures of default risk based, for example, on credit ratings stems from the fact that the dynamics of EDFs are driven primarily by the movements in equity values. As a result, EDFbased measures of credit risk have the ability to react more rapidly to deterioration in the firm's credit quality as well as to reflect more promptly changes in aggregate economic conditions.

\subsection{Descriptive Statistics}

Table 1 contains several summary statistics for our panel. Despite our focus on firms that have both equity and a portion of their debt traded in open markets, firm size - measured by sales or market capitalization - varies widely in our sample. Not surprisingly, though, most of the firms in our dataset are quite large. The median firm has more than $\$ 670$ million in sales and a market capitalization of about $\$ 2.1$ billion. About one-half of observations are associated with leverage ratios greater than one. The relatively high leverage in our sample is due in part to the steep fall in equity prices that started in the spring of 2000, which significantly reduced the market capitalization of firms, thereby driving up their leverage ratios.

\footnotetext{
${ }^{16}$ The MKMV's mapping of distances to default to EDFs restricts the probability estimates to the range between 0.02 percent and 20 percent because of sparse data beyond these points.
} 
Table 1

Summary Statistics

\begin{tabular}{|c|c|c|c|}
\hline Variable & Minimum & Median & Maximum \\
\hline Sales ( $\$$ billions) & 0.002 & 0.7 & 57 \\
\hline Mkt. Capitalization ( $\$$ billions) & 0.006 & 2.2 & 309 \\
\hline Leverage Ratio $^{a}$ & 0.02 & 0.50 & 15.9 \\
\hline Credit Spread $^{b}$ (p.p.) & 0.27 & 2.27 & 29.14 \\
\hline No. of Issues Traded & 1 & 2 & 59 \\
\hline Avg. Portfolio Maturity (years) & 1 & 8 & 30 \\
\hline Share of Traded Debt ${ }^{c}(\%)$ & 2 & 51 & 100 \\
\hline S\&P Credit Rating & $\mathrm{C} 2$ & BBB3 & AAA \\
\hline Year-Ahead EDF (\%) & 0.02 & 0.55 & 19.9 \\
\hline
\end{tabular}

Panel Dimensions

Observations $=14,124 \quad$ Firms $=918$

Min. Tenure $=4 \quad$ Median Tenure $=14 \quad$ Max. Tenure $=27$

Notes: Sample period: 1997Q1-2003Q3. In every period, the sample excludes firms with leverage ratios below the $2.5^{\text {th }}$ percentile and above the $97.5^{\text {th }}$ percentile, firms with credit spreads above the $97.5^{\text {th }}$ percentile, and firms with EDFs at exactly 20\%. Sales and market capitalization are in real chain-weighted dollars.

${ }^{a}$ The book value of long-term debt relative to market capitalization.

${ }^{b}$ Adjusted for the differential tax treatment of corporate and Treasury securities.

${ }^{c}$ The book value of traded bonds relative to the book value of total long-term debt.

Although firms in our sample generally have only a few bond issues trading at any given point in time, this publicly-traded debt represents a significant portion of their long-term debt. The median ratio of the book value of traded bonds outstanding to the book value of total long-term debt on firms' balance sheet is about one-half, suggesting that market prices on outstanding securities likely provide an accurate gauge of the marginal cost of external finance for most of the firms. Our sample also spans essentially the entire corporate credit quality spectrum-from $\mathrm{C} 2$, the "junkiest junk," to AAA, the highest grade. In terms of credit quality, the median observation is at the bottom rung of the investment-grade ladder, and it is associated with a taxadjusted spread of 227 basis points over the risk-free rate and an expected year-ahead default frequency of 55 basis points.

Our sample includes only 918 nonfinancial corporations. Nonetheless, it is representative of the aggregate economy along a number of dimensions. The upper panel of Figure 4 compares the aggregate growth rate of real sales for the firms in our panel 
Figure 4

\section{Aggregate Corporate Balance Sheets}

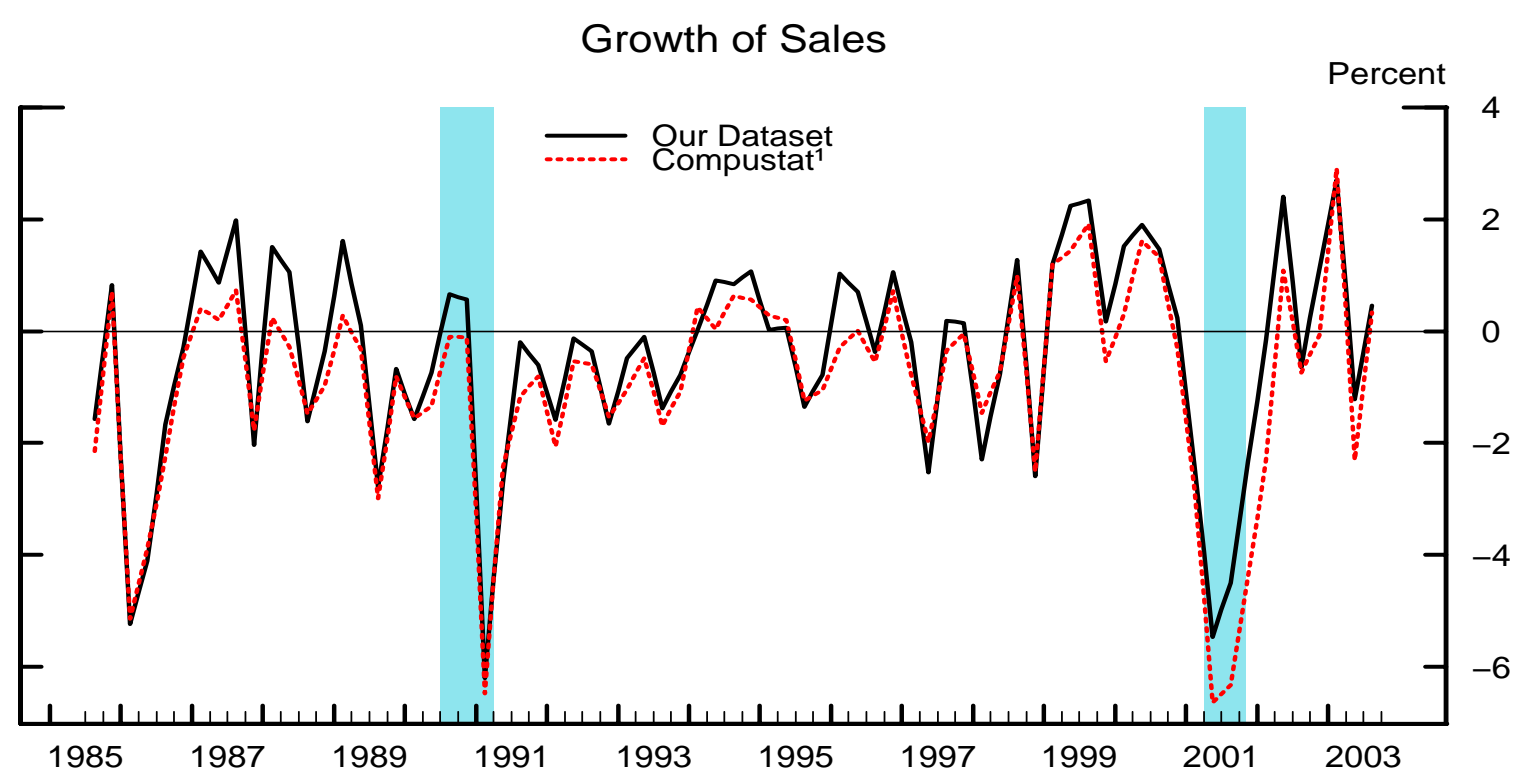

Note. Firm-level sales were deflated by the chain-weighted GDP price deflator (2000=100).

Data are seasonally adjusted.

1 All nonfinancial corporations.

\section{Leverage}

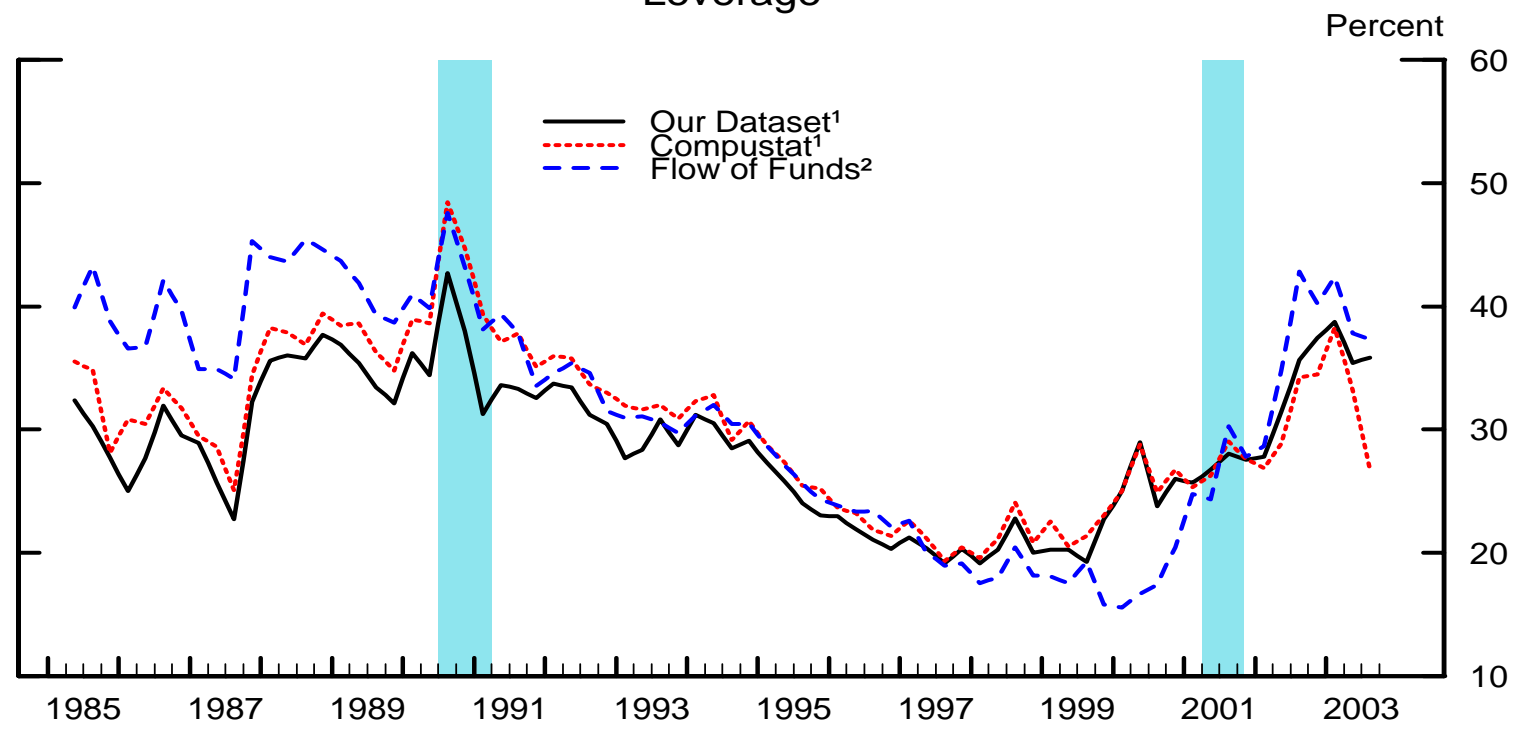

Note. Data are seasonally adjusted.

1 Median book value of long-term debt relative to market value of equity weighted by firm sales.

2 Book value of bonds and mortgages relative to market value of equity for all nonfinancial corporations. 
with the corresponding growth rate for the Compustat's entire nonfarm nonfinancial sector. The two series are highly correlated and exhibit virtually identical business cycle dynamics. The lower panel compares the sales-weighted median leverage of firms in our sample with the corresponding statistic for all nonfinancial firms in Compustat as well as with a measure of long-term leverage in the nonfinancial sector obtained from the Flow of Funds accounts. ${ }^{17}$ The three measures paint a very similar picture of the state of corporate balance sheets over time. Clearly evident is the sharp run-up in corporate leverage during the late 1980 s, followed by a steady decline over most of the past decade. Leverage in the nonfinancial corporate sector bottomed out at a very low level in the late 1990s and then rose noticeably after the bursting of the stock market bubble in the spring of 2000 .

Credit spreads in our sample are also representative of the spreads in the corporate bond market as a whole, when controlling for the maturity of bonds outstanding and the credit quality of issuers. As shown in the upper panel of Figure 5, the (weighted) median credit spread for BBB-rated debt with maturity of 7 to 10 years obtained from our sample provides a very close match to the (weighted) median spread of all nonfinancial bond issues in the Merrill lynch database. (This result holds for other rating categories and maturity buckets.) Finally, the lower panel shows that the evolution of the (weighted) median expected one-year-ahead default frequency for the firms in our sample tracks very closely the (weighted) median EDF of all nonfinancial firms in the MKMV database.

For our purposes, the two key relationships implied by the BGG framework are the leverage-spread and the leverage-default-probability schedules. These two unconditional relationships are plotted in Figure 6 using the firm-level data. ${ }^{18}$ Despite enormous variation, there is a clearly discernable pattern between leverage and credit spreads (top panel) and leverage and expected probabilities of default (bottom panel). Moreover, the contours of these relationships are broadly similar to those implied by the BGG model in Figures 2-3, in that a higher leverage is associated with a wider credit spread and a higher expected probability of defaults.

\footnotetext{
${ }^{17}$ The sales-weighted median leverage in period $t$ identifies a firm in the distribution of leverage such that firms with higher (or lower) leverage in period $t$ account for one-half of sample liabilities.

${ }^{18}$ To minimize the visual effect of outliers, we drop in each quarter firms with leverage ratios above the $97.5^{\text {th }}$ percentile and below the $97.5^{\text {th }}$ percentile, firms with credit spreads above the $97.5^{\text {th }}$ percentile, and firms with EDFs at exactly $20 \%$.
} 
Figure 5

\section{Aggregate Corporate Credit Spreads and Credit Quality}

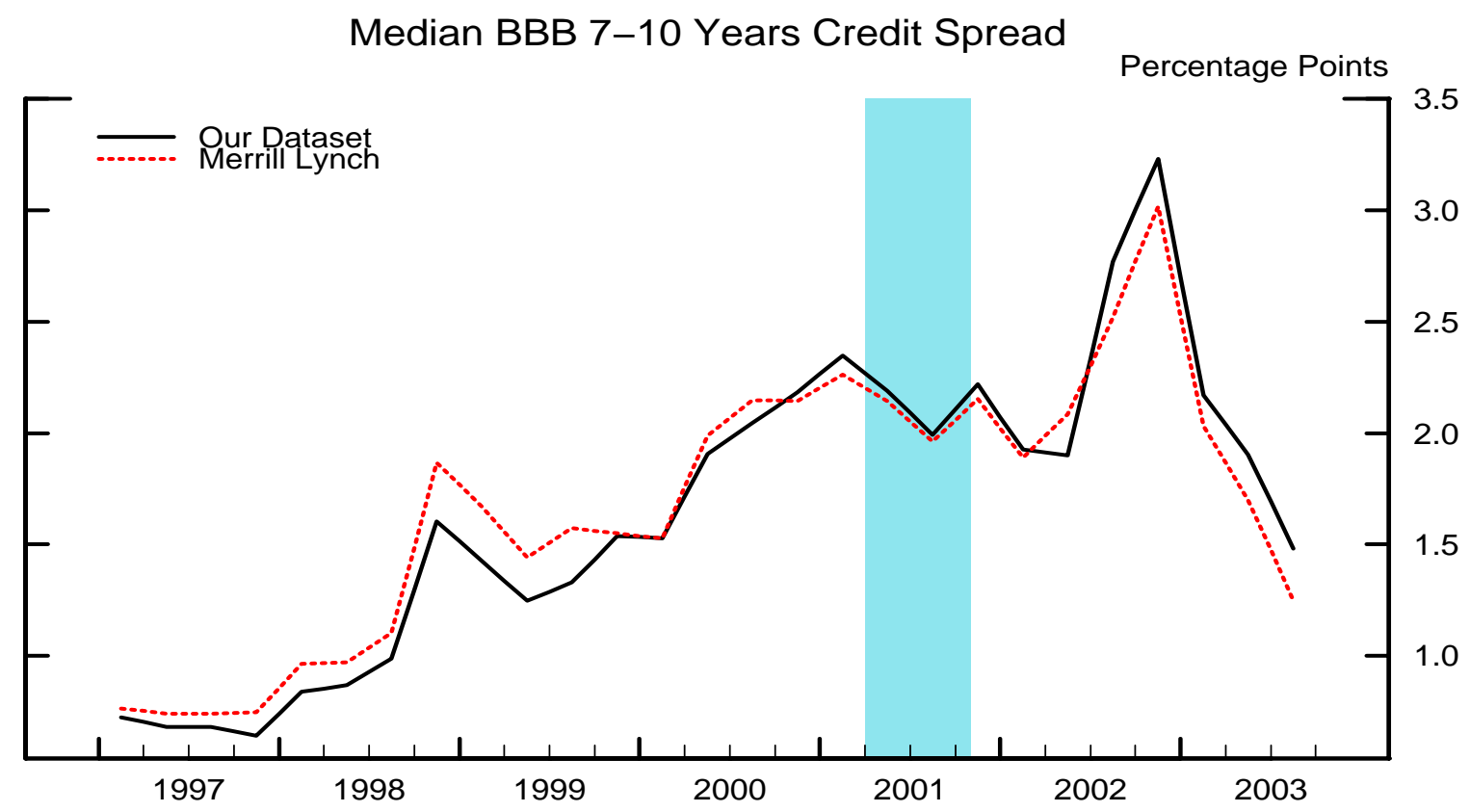

Note. Medians are weighted by the market value of bonds outstanding. Merrill Lynch data are for nonfinancial issues only.

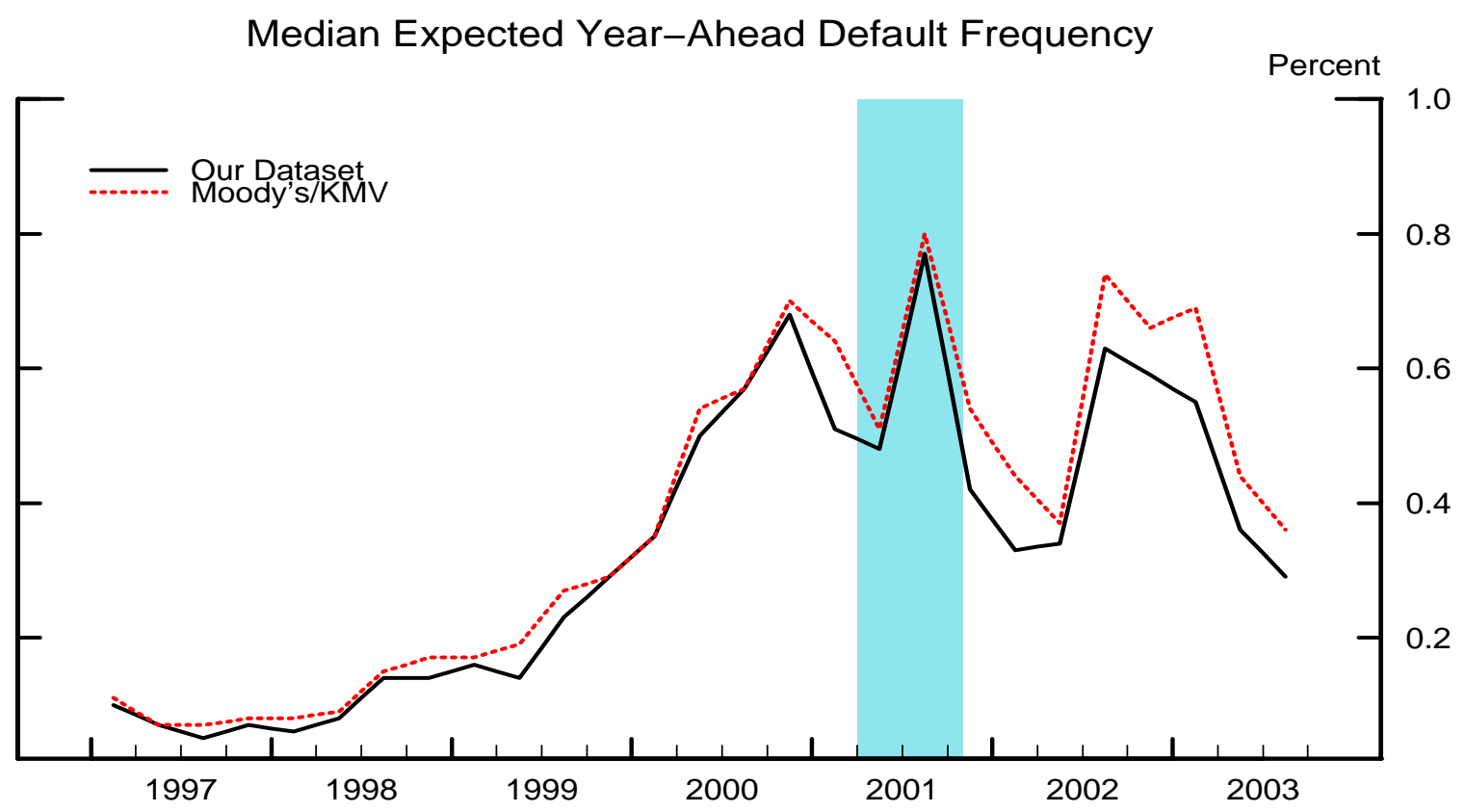

Note. Medians are weighted by the book value of liabilities. Moody's/KMV data are for nonfinancial firms only. 
Firm-Level Leverage, Credit Spreads, and Default Probabilities

\section{Leverage and Credit Spreads}

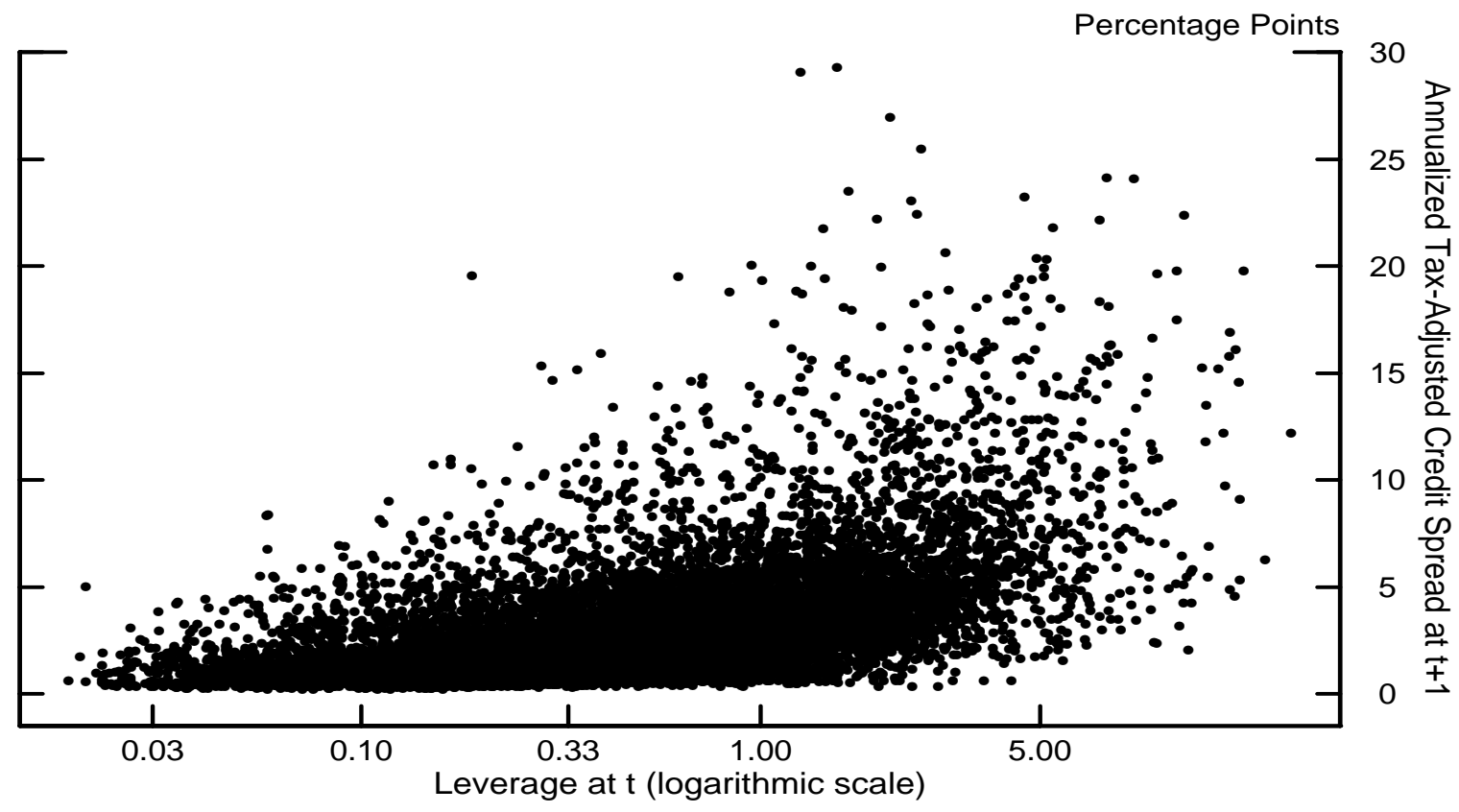

Leverage and Expected Probabilities of Default

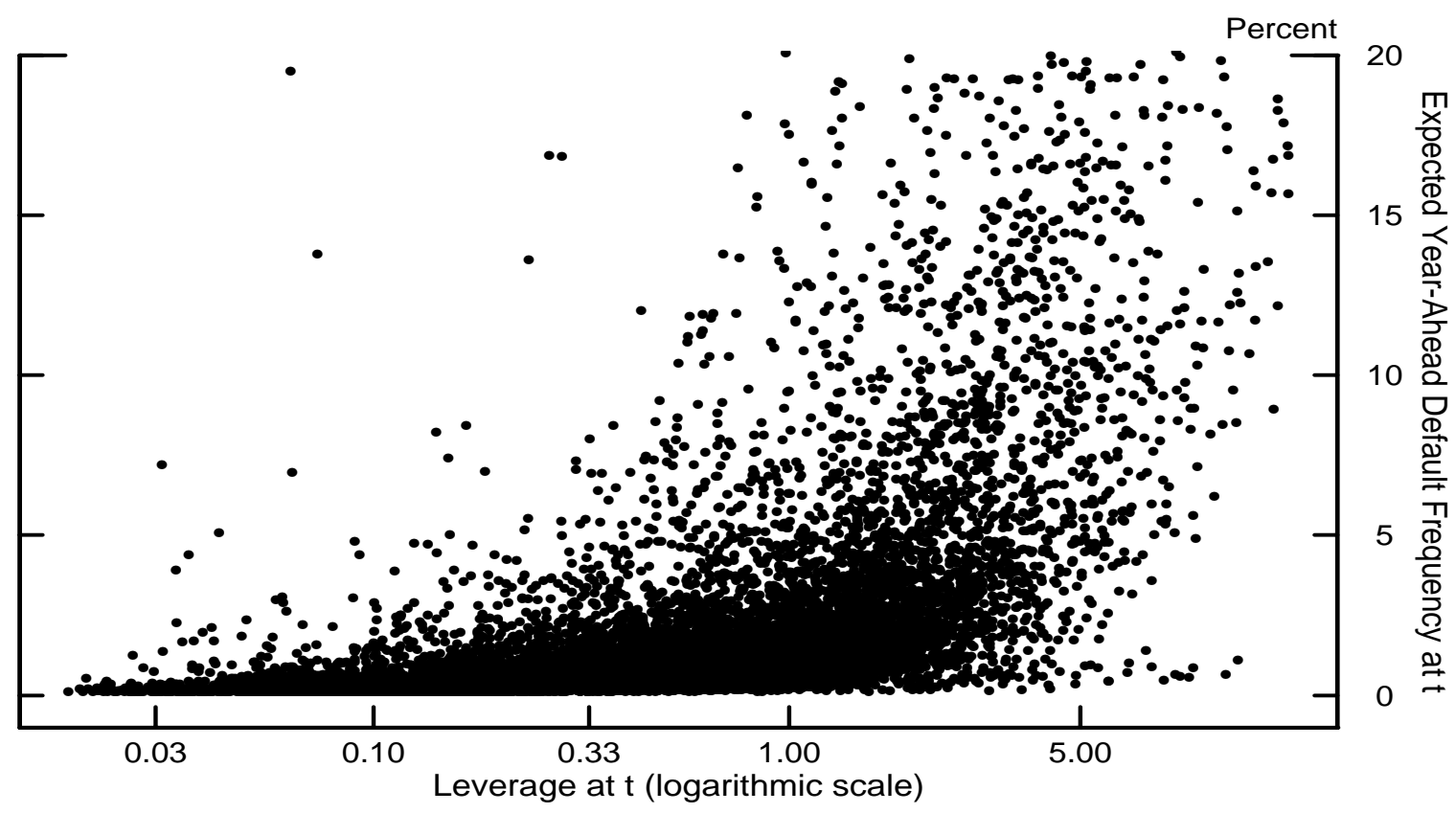




\section{Estimation Methodology}

As discussed in Section 2, the bankruptcy cost parameter $\mu$ determines the magnitude of financial market frictions in the BGG framework. Recognizing that this parameter may exhibit substantial temporal variation, we use the cross-section of firm-level observations for each time period $t$, and apply non-linear least squares (NLLS) to obtain the value of $\mu_{t}$ that minimizes the sum of squared deviations between observed credit spreads and those predicted by the model. In implementing this procedure, we allow the idiosyncratic shock variance, $\sigma_{i t}$, to vary across firms as well as time periods.

For any given value of the bankruptcy cost parameter, the predicted credit spread of a given firm $i$ at time period $t$ is computed as follows. First, using the observed leverage ratio and expected default probability, the following two equations can be solved to obtain values for the default threshhold $\bar{\omega}_{i t}$ and the idiosyncratic shock variance $\sigma_{i t}$ :

$$
\begin{aligned}
{\left[\frac{B}{N}\right]_{i, t-1} } & =-\frac{\psi^{\prime}\left(\bar{\omega}_{i t} ; \sigma_{i t}\right) \xi\left(\bar{\omega}_{i t} ; \sigma_{i t}, \mu_{t}\right)}{\psi\left(\bar{\omega}_{i t} ; \sigma_{i t}\right) \xi^{\prime}\left(\bar{\omega}_{i t} ; \sigma_{i t}, \mu_{t}\right)} ; \\
\mathrm{EDF}_{i, t-1 \mid t} & =\Phi\left(\frac{\ln \bar{\omega}_{i t}-0.5 \sigma_{i t}^{2}}{\sigma_{i t}}\right)
\end{aligned}
$$

where $[B / N]_{i, t-1}$ denotes the firm's leverage at the end of the previous quarter, and $E D F_{i, t-1 \mid t}$ denotes the probability (as of the end of quarter $t-1$ ) that firm $i$ will default in quarter $t$. Under the assumption of log-normality of the idiosyncratic shocks, the functions $\psi$ and $\xi$ are given by equations 7 and 8 , respectively, while $\Phi$ denotes the standard normal cumulative distribution function. ${ }^{19}$

Next, the predicted credit spread $\left[R^{b_{i} t} / R_{i} t\right]^{*}$ is obtained by evaluating the following expression using these values of $\bar{\omega}_{i t}^{*}$ and $\sigma_{i t}^{*}$ together with the observed leverage ratio:

$$
\left[\frac{R^{b}}{R}\right]_{i t}^{*}=\frac{\bar{\omega}_{i t}^{*} \psi^{\prime}\left(\bar{\omega}_{i t}^{*} ; \sigma_{i t}^{*}\right)\left(1+\left[\frac{B}{N}\right]_{i t-1}\right)}{\psi\left(\bar{\omega}_{i t}^{*} ; \sigma_{i t}^{*}\right) \xi^{\prime}\left(\bar{\omega}_{i t}^{*} ; \sigma_{i t}^{*}, \mu_{t}\right)-\psi^{\prime}\left(\bar{\omega}_{i t}^{*} ; \sigma_{i t}^{*}\right) \xi\left(\bar{\omega}_{i t}^{*} ; \sigma_{i t}^{*}, \mu_{t}\right)}
$$

\footnotetext{
${ }^{19}$ To match the one-period nature of the BGG framework, we convert the MKMV year-ahead expected default frequency $\left(\mathrm{EDF}_{i t \mid t+1 \ldots t+4}\right)$ to a quarterly basis using the simplifying assumption of a constant hazard rate over each four-quarter horizon; that is, $\mathrm{EDF}_{i t \mid t+1}=\left(1+\mathrm{EDF}_{i t \mid t+1 \ldots t+4}\right)^{1 / 4}-1$.
} 
Since the BGG model abstracts from various details of financial market behavior, our estimation procedure incorporates time-specific industry and ratings dummies:

$$
\left[\frac{R^{b}}{R}\right]_{i t}-\left[\frac{R^{b}}{R}\right]_{i t}^{*}=\text { RATING }_{i t-1}+\operatorname{INDUSTRY}_{i t}+\epsilon_{i t}
$$

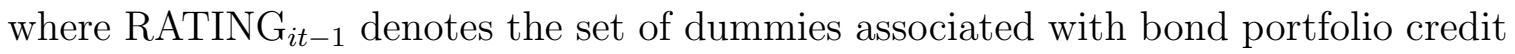
ratings at the end of period $t-1$, and INDUSTRY $i t$ denotes the set of industry dummies; the coefficients on these dummies are allowed to vary over time. ${ }^{20}$ The stochastic disturbance $\epsilon_{i t}$ is assumed to have zero mean and to be independent across firms, but may exhibit time-varying heteroskedasticity; that is, $\mathrm{E}\left[\epsilon_{i t}\right]=0, \mathrm{E}\left[\epsilon_{i t}^{2}\right]=\nu_{i t}^{2}$, and $\mathrm{E}\left[\epsilon_{i t} \epsilon_{j t}\right]=0$, for all $i \neq j$.

The rating dummies are included to control for liquidity factors that arise from the fact that certain corporate bonds trade rather infrequently, implying a relatively thin secondary markets for some securities. ${ }^{21}$ In such a case, a credit spread will include a premium to compensate investors for the risk of having to sell or hedge a position in an illiquid market. As shown by Delianedis and Geske (2001), this liquidity risk is correlated with default risk and accounts for a significant portion of observed credit spreads. Controlling for industry differences is potentially important because our dataset, though rich in the cross-sectional dimension, spans a single business cycle dominated by the bursting of the high-tech bubble.

Following this approach, the residual vector $\left(\epsilon_{1 t}, \ldots \epsilon_{n_{t} t}\right)$ can be computed for any given value of $\mu$. Thus, for each time period, we start with an initial guess for this parameter, and then utilize a standard optimization algorithm to obtain the NLLS estimator $\hat{\mu}_{t}$ that minimizes the sum of squared residuals. ${ }^{22}$

\footnotetext{
${ }^{20}$ Credit rating indicators are based on the average of the S\&P ratings of the firm's outstanding bond issues, weighted by the market value of bonds. The resulting portfolio credit ratings were condensed into nine categories: AAA, AA, A, BBB, BB, B, CCC, CC, and C. Industry effects are based on the 3-digit North American Industry Classification System (NAICS).

${ }^{21}$ See Warga (1991) for a discussion of problems associated with high-frequency corporate bond prices and the use of "grid-based" pricing.

${ }^{22}$ For each time period, we utilized an extensive grid of initial guesses to ensure that the NLLS estimator reached the global minimum of the objective function.
} 


\section{$5 \quad$ Empirical Results}

\subsection{Benchmark Estimates of Financial Market Frictions}

Figure 7 shows the evolution of the estimated bankruptcy cost parameter $\mu$ over our sample period. From early 1997 to the end of 1999, the point estimate of $\mu$ appears to be quite stable, hovering in the range between 0.08 and 0.16 . One clear exception during this period is the substantially larger estimate for 1998Q4. This jump in estimated bankruptcy costs reflects the turbulence in financial markets following the Russian default and the LTCM crisis in the late summer of that year. Smoothing through the 1998Q4 spike, the average estimate of $\mu$ during this period is remarkably close to 0.12 , the value chosen by BGG in the steady-state calibration of their model. Our estimates are also within the range of bankruptcy costs estimated by Altman (1984) for a sample of industrial firms that declared bankruptcy in the mid-1970s. ${ }^{23}$

The bursting of the stock market bubble in the spring of 2000 significantly depressed equity valuations, causing an increase in corporate leverage. By the onset of the last NBER-dated recession in March 2001, credit spreads also had widened significantly. In the context of the BGG model, however, the rise in leverage apparently was insufficient to account fully for the runup in credit spreads. A part of the increase in credit spreads during this period reflected an increase in the external finance premium, as our estimates of $\bar{\omega}_{i t}^{*}$ only rose slightly (see equation 6). ${ }^{24}$ The increase in the external finance premium also did not come about from higher $\sigma_{i t}^{*}$ 's, the point to which we return later. Instead, it stemmed from an increase in bankruptcy costs, as evidenced by our estimates of $\mu$, which more than doubled over this period.

After declining moderately over the course of the 2001 downturn and into early 2002, the estimated $\mu$ rose sharply in the latter half of the year. This increase likely reflected a further plunge in share prices and the balooning of credit spreads, as the post-Enron wave of corporate governance scandals and heightened geopolitical tensions that preceeded the invasion of Iraq rattled investors' confidence. For this period as a whole, our estimates of bankruptcy costs are much closer to the average

\footnotetext{
${ }^{23}$ Altman's (1984) estimates of bankruptcy costs include both the direct and indirect costs and average between 11 percent and 17 percent of the value of the firm. Direct costs - explicit administrative costs paid by the debtor during the reorganization/liquidation process - were taken from the bankruptcy records of individual firms. Measures of indirect costs, namely lost profits, were estimated.

${ }^{24}$ For example, the sales-weighed median $\bar{\omega}_{i t}^{*}$ rose from 0.218 to 0.236 in 2000.
} 
Figure 7

\section{NLLS Estimates of Bankruptcy Cost Parameter $\mu$}

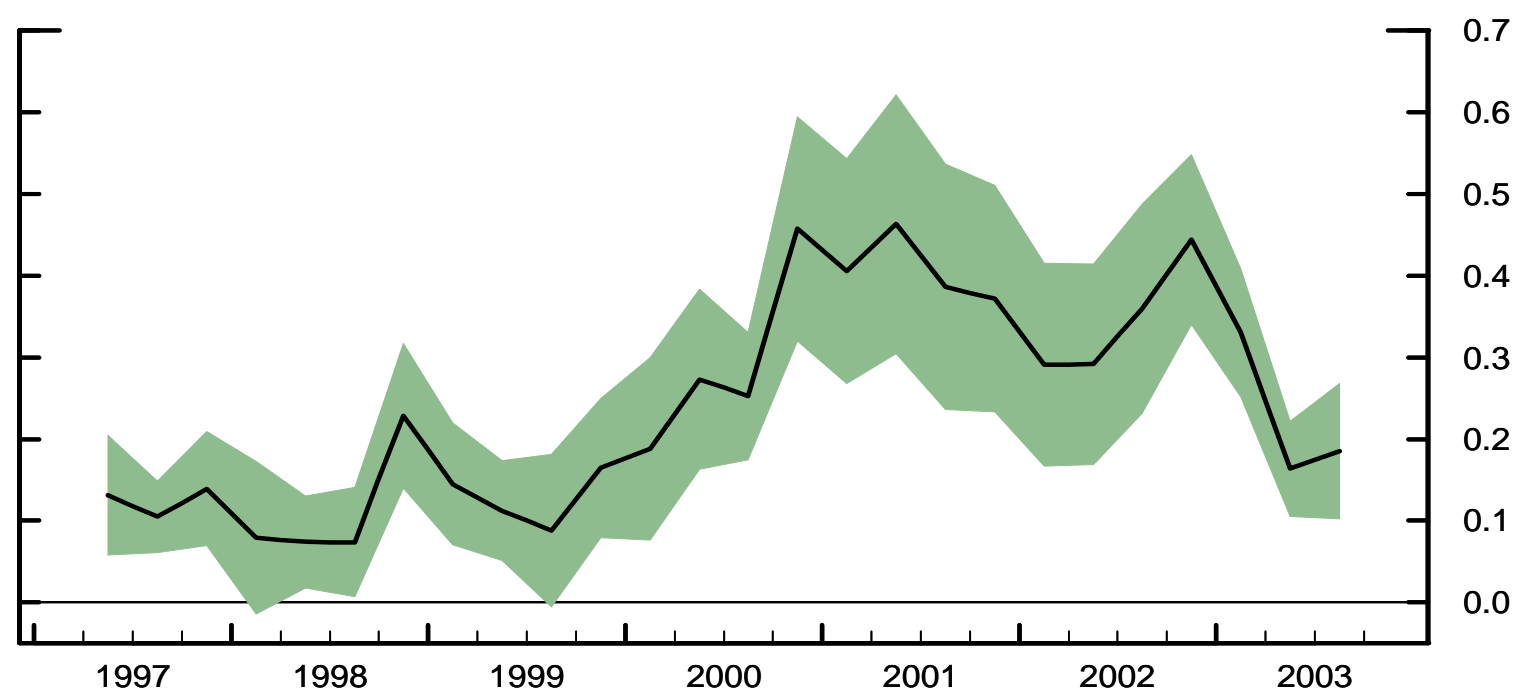

Note. The shaded region represents $+/-$ two standard error bands computed using a heteroscedasticity-consistent asymptotic covariance matrix.

liquidation costs calculated by Alderson and Betker (1995) for a sample of firms that completed Chapter 11 bankruptcy proceedings between 1982 and 1993. In 2003, as the economy recovered, stock prices started to rise, and credit spreads narrowed, the point estimate of $\mu$ declined back to the range that prevailed at the beginning of our sample period.

According to standard errors in Table 2, estimates of $\mu$ are not statistically different from zero at conventional significance levels in just two periods (1998Q1 and 1999Q3). In all other periods, we overwhelmingly reject the null hypothesis of no financial market frictions. The benchmark specification also fits the data remarkably well, explaining as much as 88 percent of the cross-sectional variance in credit spreads during our sample period. Likelihood ratio tests strongly reject the exclusion of credit rating effects throughout the sample period, while industry effects are statistically significant only in the aftermath of the Russian default in late 1998 and from the end of 2000 forth. These results suggest that factors other than bankruptcy costs and expected probabilities of default play an important role in determining spreads on corporate bonds, especially during periods of heightened volatility in financial markets. 
Table 2

NLLS Estimates of Bankruptcy Cost Parameter $\mu$

\begin{tabular}{ccccccc}
\hline \hline Period & Obs. & Estimate & Std. Err. $^{a}$ & Adj. $R^{2}$ & $\operatorname{Pr}>\lambda_{R}{ }^{b}$ & $\operatorname{Pr}>\lambda_{I}{ }^{c}$ \\
\hline 1997Q2 & 327 & 0.131 & 0.037 & 0.88 & $<.01$ & 0.29 \\
1997Q3 & 349 & 0.105 & 0.022 & 0.88 & $<.01$ & 0.15 \\
1997Q4 & 368 & 0.139 & 0.035 & 0.88 & $<.01$ & 0.57 \\
1998Q1 & 392 & 0.080 & 0.047 & 0.87 & $<.01$ & 0.68 \\
1998Q2 & 399 & 0.074 & 0.028 & 0.83 & $<.01$ & 0.72 \\
1998Q3 & 427 & 0.074 & 0.034 & 0.84 & $<.01$ & 0.39 \\
1998Q4 & 442 & 0.228 & 0.044 & 0.85 & $<.01$ & $<.01$ \\
1999Q1 & 458 & 0.145 & 0.037 & 0.81 & $<.01$ & $<.01$ \\
1999Q2 & 460 & 0.112 & 0.031 & 0.77 & $<.01$ & 0.05 \\
1999Q3 & 438 & 0.088 & 0.047 & 0.72 & $<.01$ & 0.29 \\
1999Q4 & 442 & 0.165 & 0.043 & 0.69 & $<.01$ & 0.16 \\
2000Q1 & 463 & 0.188 & 0.056 & 0.69 & $<.01$ & 0.53 \\
2000Q2 & 476 & 0.273 & 0.055 & 0.71 & $<.01$ & 0.59 \\
2000Q3 & 487 & 0.253 & 0.039 & 0.70 & $<.01$ & 0.12 \\
2000Q4 & 492 & 0.458 & 0.069 & 0.65 & $<.01$ & $<.01$ \\
2001Q1 & 490 & 0.406 & 0.069 & 0.62 & $<.01$ & $<.01$ \\
2001Q2 & 500 & 0.463 & 0.079 & 0.70 & $<.01$ & $<.01$ \\
2001Q3 & 489 & 0.386 & 0.075 & 0.73 & $<.01$ & $<.01$ \\
2001Q4 & 480 & 0.372 & 0.070 & 0.74 & $<.01$ & $<.01$ \\
2002Q1 & 497 & 0.291 & 0.062 & 0.76 & $<.01$ & $<.01$ \\
2002Q2 & 508 & 0.292 & 0.062 & 0.75 & $<.01$ & $<.01$ \\
2002Q3 & 502 & 0.359 & 0.064 & 0.76 & $<.01$ & $<.01$ \\
2002Q4 & 523 & 0.444 & 0.052 & 0.73 & $<.01$ & $<.01$ \\
2003Q1 & 537 & 0.330 & 0.039 & 0.77 & $<.01$ & $<.01$ \\
2003Q2 & 523 & 0.164 & 0.029 & 0.77 & $<.01$ & $<.01$ \\
2003Q3 & 520 & 0.186 & 0.041 & 0.77 & $<.01$ & $<.01$ \\
\hline \hline
\end{tabular}

Notes: In every period, the sample excludes firms with leverage ratios below the $2.5^{\text {th }}$ percentile and above the $97.5^{\text {th }}$ percentile, firms with credit spreads above the $97.5^{\text {th }}$ percentile, and firms with EDFs at exactly $20 \%$.

${ }^{a}$ Computed using a heteroscedasticity-consistent asymptotic covariance matrix; see White (1980).

${ }^{b} p$-value for the likelihood ratio test statistic $\lambda_{R}$ of the exclusion of fixed credit rating effects.

${ }^{c} p$-value for the likelihood ratio test statistic $\lambda_{I}$ of the exclusion of fixed industry effects. 
Using our estimates of the bankruptcy cost parameter $\mu_{t}$ and the corresponding solutions for the default productivity threshold $\bar{\omega}_{i t}^{*}$ and the standard deviation of the idiosyncratic productivity shock $\sigma_{i t}^{*}$, we can calculate the model-implied recovery rate. This provides an alternative metric by which to evaluate the BGG model and the quantitative relevance of bankruptcy costs during the last economic downturn. Figure 8 shows the evolution over our sample period of both the average actual recovery rate at default and the average model-implied recovery rate, defined as

$$
\frac{\left(1-\hat{\mu}_{t}\right) R_{t}^{k}\left(B_{i t-1}+N_{i t-1}\right)}{B_{i t-1}} \times E\left[\omega_{i t} \mid \omega_{i t}<\bar{\omega}_{i t}^{*}\right],
$$

where $E\left[\omega_{i t} \mid \omega_{i t}<\bar{\omega}_{i t}^{*}\right]$ is the expected realization of the productivity disturbance $\omega_{i t}$ conditional on being on default. ${ }^{25}$ The model-implied recovery rate is much higher than the actual recovery rate on corporate bonds, particularly so in the pre-recession period. As shown in the next subsection, the exclusion of credit rating effects generates bigger estimates of the bankruptcy parameter $\mu_{t}$ and, consequently, smaller model-implied recovery rates. Qualitatively, however, actual and model-implied recovery rates behave similarly even in this benchmark case, decreasing before the economic downturn and rising since 2001. Importantly, the model-implied recovery rate in the case without bankruptcy costs $(\mu=0)$ is unrealistically high and displays no cyclical pattern. This implies that a substantial degree of financial market frictions is a necessary ingredient if one wish to explain the recovery rate on corporate bonds during the last recession.

An important advantage of our strategy of estimating a structural model is that we can derive firm-specific estimates of the unobservable external finance premium. Movements in the external finance premium over the business cycle reveal how endogenous developments in financial markets work to amplify and propagate shocks to the economy. In fact, with procyclical borrowers' net worth - due to the procyclicality of profits and equity valuations - the external finance premium will move counter-

${ }^{25}$ Assuming $\omega_{i t}$ is log normally distributed, we can write this conditional expectation as

$$
E\left[\omega_{i t} \mid \omega_{i t}<\bar{\omega}_{i t}^{*}\right]=\frac{\Phi\left(\frac{\ln \bar{\omega}_{i t}^{*}-0.5 \sigma_{i t}^{* 2}}{\sigma_{i t}^{*}}\right)}{\Phi\left(\frac{\ln \bar{\omega}_{i t}^{*}+0.5 \sigma_{i t}^{* 2}}{\sigma_{i t}^{*}}\right)}
$$

To obtain $R_{t}^{k}$ we multiply the model-implied external finance premium $\left[\frac{R^{k}}{R}\right]_{i t}^{*}$ by the gross risk-free rate $R_{t}$, which is assumed to be constant at an annual rate of 3 percent. 
Figure 8

\section{Recovery Rates on Defaulted Bonds}

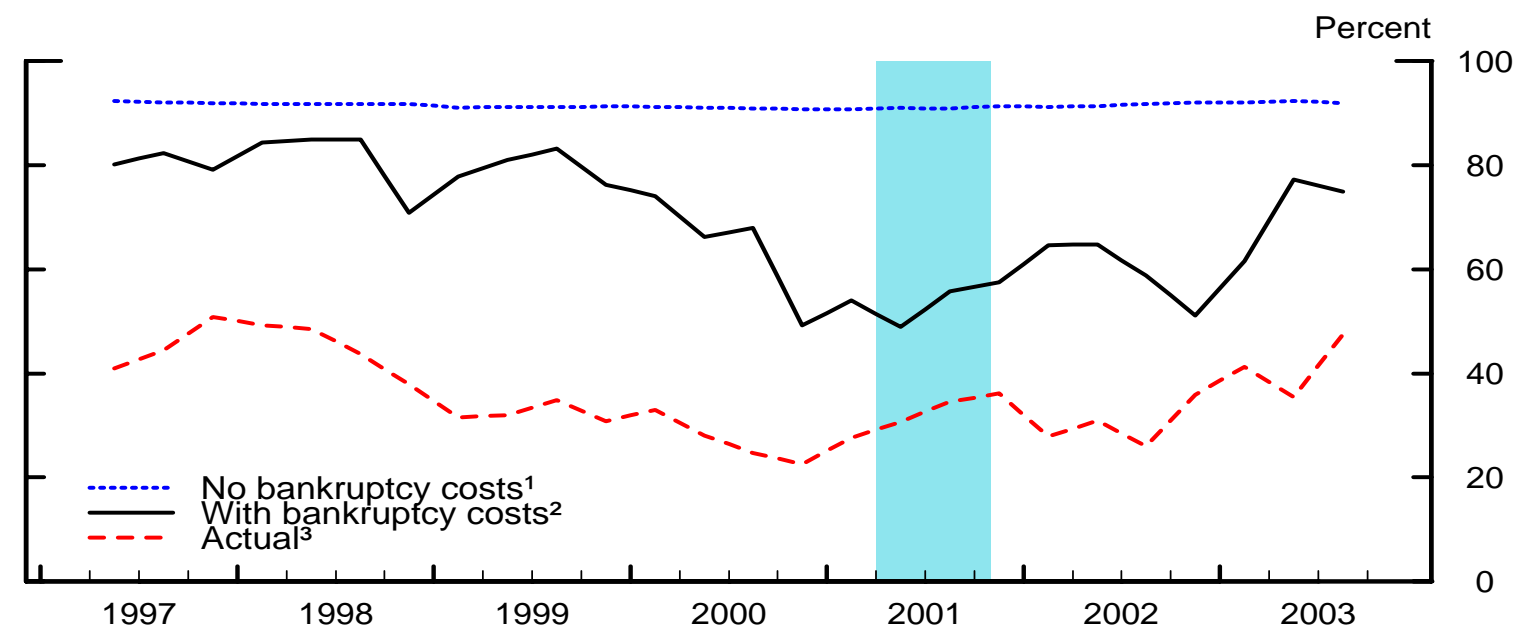

${ }_{1}^{1}$ Average model-implied recovery rate with $\mu=0$, weighted by the book value of bonds outstanding.

2 Average model-implied recovery rate with estimated $\mu$, weighted by the book value of bonds outstanding.

${ }_{3}$ Average recovery rate at default weighted by the book value of the defaulted bond issue (four-quarter moving average).

cyclically, amplifying the swings in borrowing and, consequently, in investment and output.

Figure 9 shows the cyclical behavior of the model-implied external finance premium calculated using the solutions for $\bar{\omega}_{i t}^{*}$ and $\sigma_{i t}^{*}$ and our estimates of the bankruptcy cost parameter $\mu_{t}$. Smoothing through the Russian default in late 1998, the modelimplied external finance premium was close to zero across the entire cross-section of firms until the end of 1999. As stock prices began to slide in early 2000, causing a decline in firms' net worth (i.e., market capitalization) and an increase in corporate leverage, the external finance premium rose sharply, and the increase is economically significant. Firms that account for a half of aggregate sample sales experienced an increase in the external finance premium of at least 150 basis points, while firms that account for one quarter of aggregate sample sales faced an increase in the external finance premium of more than 300 basis points. The external finance premium started to decline at the end of the NBER-date recession but then jumped up again at the end of 2002 in response to concerns about corporate governance.

To investigate the interaction between the cyclical behavior of our estimates of $\mu$ and the dynamics of the external finance premium over the latest business cycle, 
Model-Implied External Finance Premium
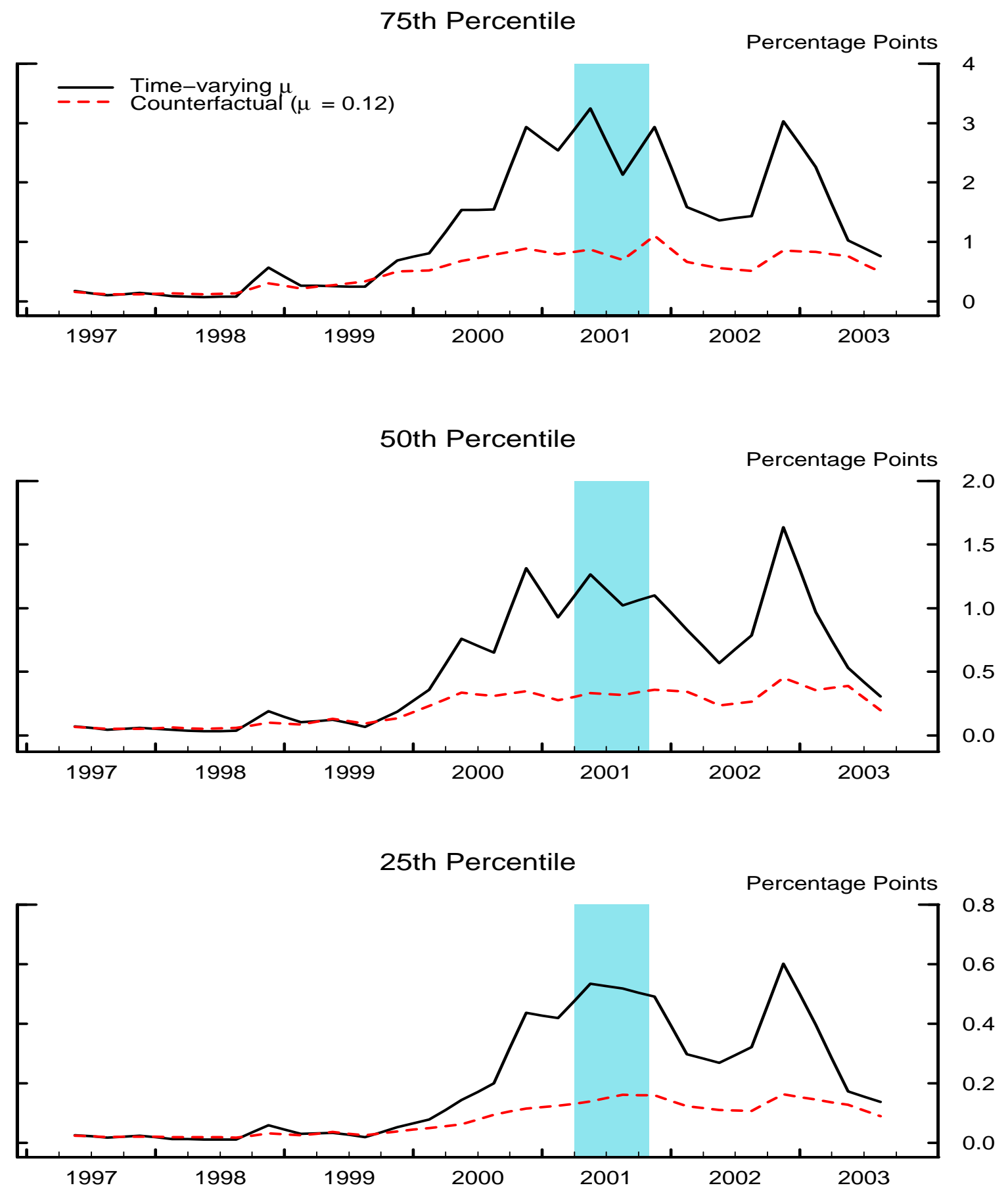

Note. Percentiles are weighted by real sales. The counterfactual excercise with a constant $\mu=0.12$ uses the firm-specific variance and productivity threshold obtained from estimating a time-varying $\mu$. 
we consider a counterfactual scenario with a time-invariant $\mu$ set equal 0.12 , the benchmark calibration of BGG. We then use model-implied $\sigma_{i t}^{*}$ and $\bar{\omega}_{i t}^{*}$ computed at the time-varying NLLS estimate of $\mu$. As shown in Figure 9, time variations in $\hat{\mu}_{t}$ are necessary to generate economically significant swings in the model-implied external finance premium. The counterfactual scenario, in fact, implies very small movements in the external finance premium over the entire cross-section of firms. Such small movements are difficult to reconcile with the sharp drop in capital spending during the latest economic downturn, unless one is willing to assume a very large elasticity of investment with respect to the external finance premium.

Nevertheless, one might argue that the sharp increase in the external finance premium during the latest recession stemmed instead from an increase in the idiosyncratic risk. In fact, according to Figure 2 and 3, a bigger external finance premium can be associated with both a bigger bankruptcy cost parameter $\mu$ and higher volatility of the idiosyncratic risk $\sigma$. As shown in Figure 10, however, the runup in the external finance premium cannot be attributed to a large increase in the idiosyncratic risk. The model-implied volatility parameter $\sigma$ for the sales-weighted median firm is fairly constant over the business cycle, despite a noticeable increase in the expected default probability. ${ }^{26}$ The relatively stable $\sigma$ appers to confirm our account of the latest economic downturn, according to which to explain the large movements in credit spreads and the external finance premium, you do need substantial time variation in the bankruptcy cost parameter $\mu$.

\footnotetext{
${ }^{26}$ In terms of Figure 2 and 3, the intuition is as follows. Small changes in the volatility of idiosyncratic risk cause large and unlikely variations in credit spread and external finance premium. On the contrary, significant changes in the bankruptcy parameter imply relatively smaller variations in credit spread and external finance premium.
} 
Figure 10

\section{Idiosyncratic Risk and Probability of Default}

Median Model-Implied $\sigma$

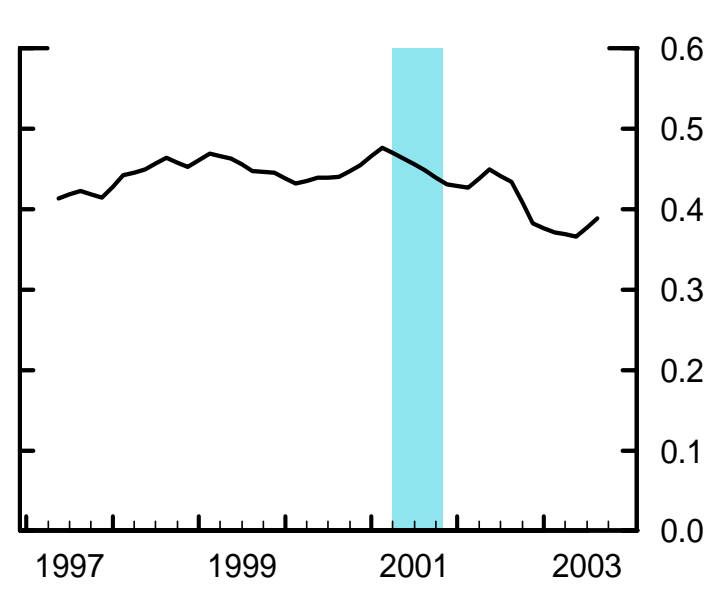

Median Year-Ahead EDF

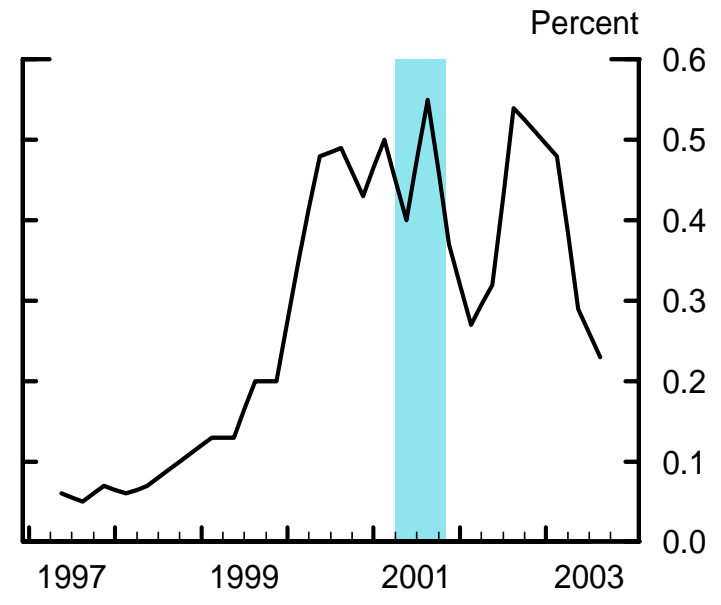

Note. Medians are weighted by real sales.

\subsection{Excluding Credit Rating Effects}

The main reason for including credit ratings in our credit spread equation 12 is that they represent a reasonable proxy for liquidity factors. As already mentioned, corporate bonds can include a liquidity premium due to the fact that markets are at times relatively thin and illiquid. To analyze whether liquidity factors are indeed a significant component of observed credit spreads and to shed some light on their interaction with financial market frictions, we reestimate the time-varying bankruptcy parameter $\mu$ without including credit rating effects.

As shown in the upper panel of Figure 11, excluding credit ratings generates a significantly larger estimates of the bankruptcy parameter $\mu_{t}$, though the time-series pattern remains the same. ${ }^{27}$ According to Table 3 , the fit of the model with industry effects alone is about half as good as the benchmark specification that includes both fixed credit rating and industry effects. This suggests that credit ratings might be picking up an important component of the residual spread in equation 12, which

\footnotetext{
${ }^{27}$ Although industry effects are statistically significant in the benchmark specification - at least during the latter half of our sample period - their exclusion has a negligible effect on the estimates of $\mu$.
} 


\section{Estimates Without Credit Rating Effects}

\section{NLLS Estimates of the Bankruptcy Cost Parameter $\mu$}

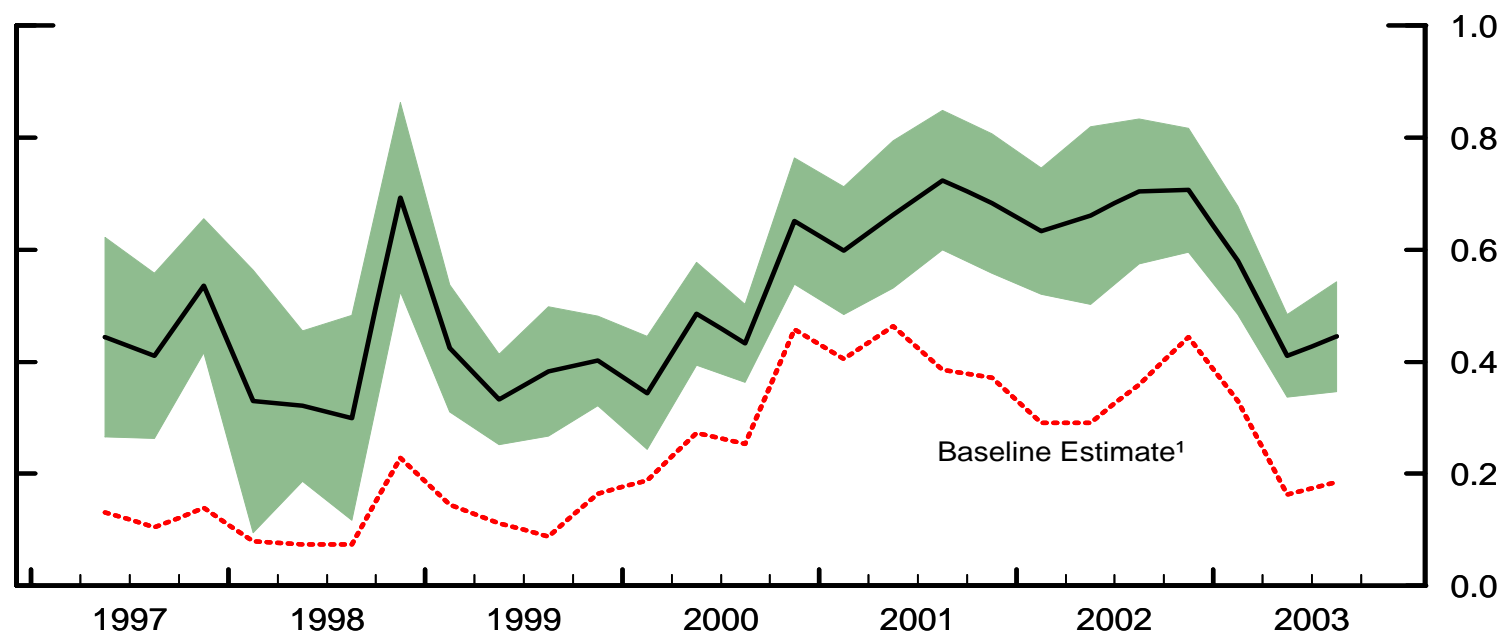

Note. The shaded region represents +/- two standard error bands computed using a heteroscedasticity-consistent asymptotic covariance matrix. The model includes fixed industry (3-digit NAICS) effects.

1 See Figure 6.

\section{Recovery Rates on Defaulted Bonds}

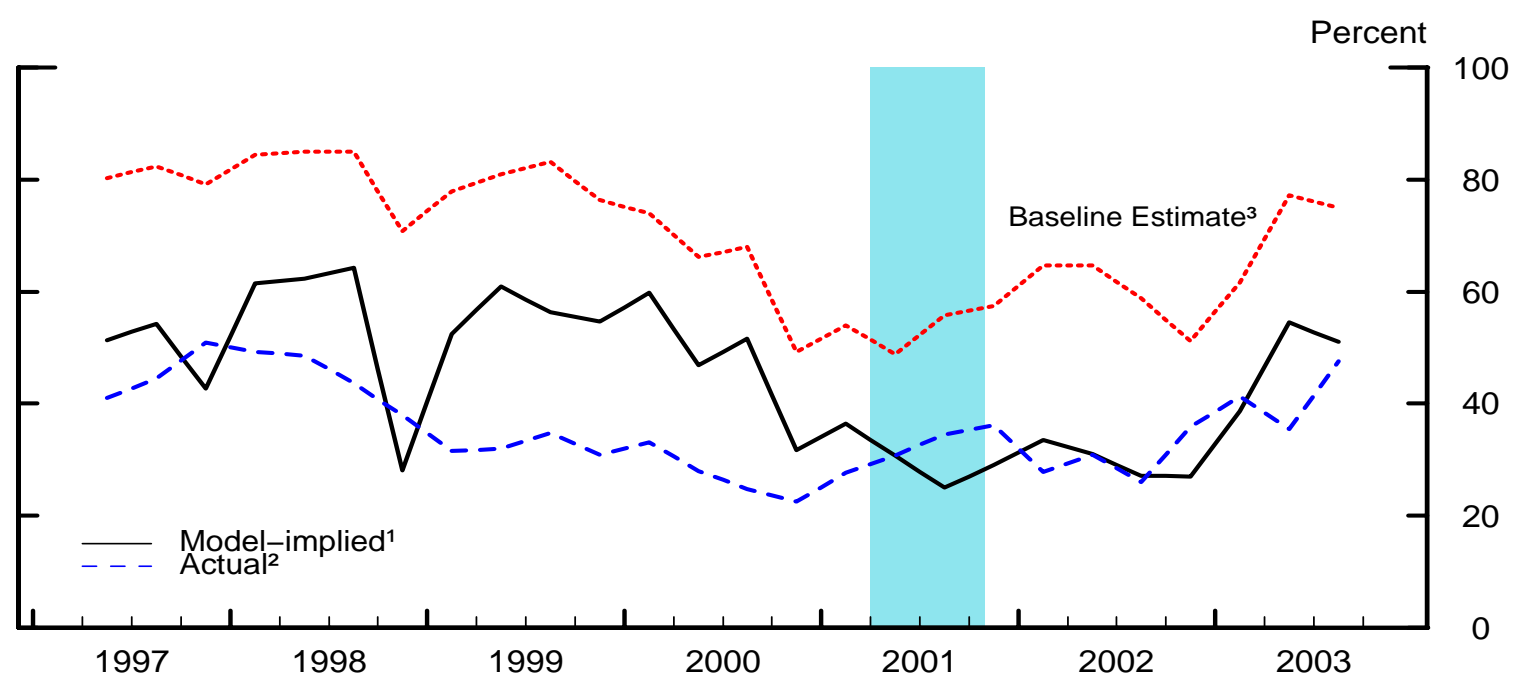

${ }_{1}^{1}$ Average model-implied recovery rate weighted by the book value of bonds outstanding.

${ }^{2}$ Average recovery rate at default weighted by the book value of the defaulted bond issue (four-quarter moving average).

${ }^{3}$ See Figure 7. 
Table 3

NLLS Estimates of Bankruptcy Cost Parameter $\mu$

\begin{tabular}{cccccc}
\hline \hline Period & Obs. & Estimate & Std. Err. $^{a}$ & Adj. $R^{2}$ & Pr $>\lambda_{I}{ }^{b}$ \\
\hline 1997Q2 & 327 & 0.144 & 0.041 & 0.45 & $<.01$ \\
1997Q3 & 349 & 0.105 & 0.029 & 0.41 & $<.01$ \\
1997Q4 & 368 & 0.139 & 0.040 & 0.47 & $<.01$ \\
1998Q1 & 392 & 0.080 & 0.051 & 0.40 & $<.01$ \\
1998Q2 & 399 & 0.074 & 0.030 & 0.36 & $<.01$ \\
1998Q3 & 427 & 0.074 & 0.032 & 0.38 & $<.01$ \\
1998Q4 & 442 & 0.239 & 0.046 & 0.49 & $<.01$ \\
1999Q1 & 458 & 0.163 & 0.038 & 0.48 & $<.01$ \\
1999Q2 & 460 & 0.121 & 0.031 & 0.49 & $<.01$ \\
1999Q3 & 438 & 0.106 & 0.044 & 0.42 & $<.01$ \\
1999Q4 & 442 & 0.178 & 0.048 & 0.49 & $<.01$ \\
2000Q1 & 463 & 0.193 & 0.052 & 0.52 & $<.01$ \\
2000Q2 & 476 & 0.275 & 0.050 & 0.56 & $<.01$ \\
2000Q3 & 487 & 0.262 & 0.038 & 0.59 & $<.01$ \\
2000Q4 & 492 & 0.496 & 0.063 & 0.58 & $<.01$ \\
2001Q1 & 490 & 0.472 & 0.064 & 0.52 & $<.01$ \\
2001Q2 & 500 & 0.485 & 0.077 & 0.60 & $<.01$ \\
2001Q3 & 489 & 0.400 & 0.078 & 0.58 & $<.01$ \\
2001Q4 & 480 & 0.401 & 0.079 & 0.53 & $<.01$ \\
2002Q1 & 497 & 0.291 & 0.058 & 0.52 & $<.01$ \\
2002Q2 & 508 & 0.290 & 0.062 & 0.53 & $<.01$ \\
2002Q3 & 502 & 0.349 & 0.062 & 0.54 & $<.01$ \\
2002Q4 & 523 & 0.443 & 0.055 & 0.54 & $<.01$ \\
2003Q1 & 537 & 0.342 & 0.040 & 0.54 & $<.01$ \\
2003Q2 & 523 & 0.186 & 0.029 & 0.47 & $<.01$ \\
2003Q3 & 520 & 0.203 & 0.043 & 0.46 & $<.01$ \\
\hline \hline
\end{tabular}

Notes: In every period, the sample excludes firms with leverage ratios below the $2.5^{\text {th }}$ percentile and above the $97.5^{\text {th }}$ percentile, firms with credit spreads above the $97.5^{\text {th }}$ percentile, and firms with EDFs at exactly $20 \%$.

${ }^{a}$ Computed using a heteroscedasticity-consistent asymptotic covariance matrix; see White (1980).

${ }^{b} p$-value for the likelihood ratio test statistic $\lambda_{I}$ of the exclusion of fixed industry effects. 
Figure 12

\section{Leverage and Volatility of Idiosyncratic Risk}

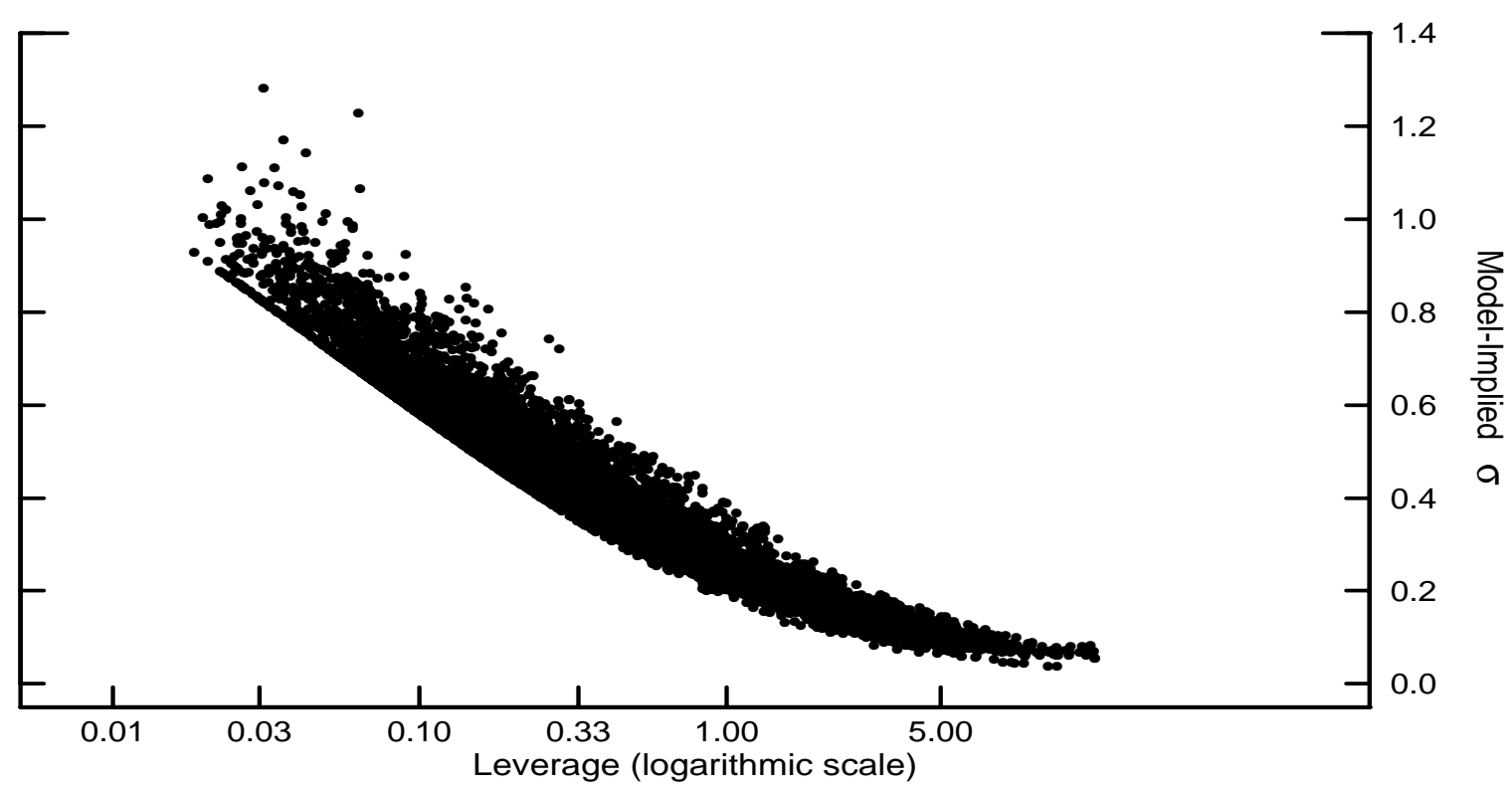

cannot be explained by the expected default probabilities derived from the optiontheoretic framework underlying the MKMV approach. Thus, once credit rating effects are excluded, the model-implied spread $\left[\frac{R^{b}}{R}\right]_{i t}^{*}$ would incorporate different sorts of financial market frictions - bankruptcy costs and liquidity premiums - and would be likely wider, requiring in turn a bigger $\hat{\mu}_{t}$.

The fit of the model, under the specification that excludes credit rating effects, is greatly improved if we use the model-implied recovery rate as an alternative metric to evaluate the BGG framework. In fact, as shown in the lower panel of Figure 11, the model-implied recovery rate is now much closer to the actual recovery rate on defaulted bonds, particularly since early 2001.

\subsection{Limitations of the BGG Framework}

In addition to the time-varying bankruptcy cost parameter $\mu_{t}$, the other (unobservable) key parameter of the BGG model that we solve for is $\sigma_{i t}$, the firm-specific, time-varying standard deviation of the idiosyncratic productivity shock. As shown in Figure 12, the model implies a strong prediction between firms' leverage and the 
volatility of idiosyncratic risk. In particular, firms with higher leverage display a smaller variance of their returns to capital.

This relationship between leverage and volatility of the idiosyncratic risk is somehow counterintuitive, as firms with high leverage are generally thought to be riskier than firms with low leverage. There appear to be two reasons for this result. The first reason has to do with the assumption that $\omega_{i t}$ is distributed log-normally. Although useful to obtain easily tractable expressions for $\psi\left(\bar{\omega}_{i t} ; \sigma\right)$ and $\xi\left(\bar{\omega}_{i t} ; \sigma, \mu\right)$, this assumption implies that the leverage-spread schedule is extremely steep. As a result, the only way for the model to fit the data is to assign a lower $\sigma_{i t}$ to a firm that experienced an increase in its leverage. ${ }^{28}$

The second reason is the assumption of one-period debt in the BGG model, implying that the marginal and the average cost of external finance coincide in the model. By contrast, credit spreads in our dataset, although they likely represent an accurate measure of the marginal cost of external finance, are certainly a poor measure of the average cost of external finance, as long-term bonds have a fixed coupon payment and in many cases were issued before the drop in stock prices.

\footnotetext{
${ }^{28}$ As shown in Figure 3, the leverage-spread schedule shifts to the right as $\sigma$ gets smaller, implying a smaller spread for given leverage.
} 


\section{Directions for Future Research}

In future research we plan to extend our work in several directions. From an empirical point of view, we plan to use our new firm-level dataset to investigate the degree of non-linearity and the cyclical variations of the spread-leverage schedule. This relates to the Bernanke and Campbell's (1988) so-called "financial fragility" argument, according to which shocks to the economy have different effects on high- and low-debt firms. Furthermore, we want to use our firm-level dataset to examine the link between firm-specific credit spreads and investment expenditures.

From a theoretical point oif view, it would be interesting to consider the implications of greater heterogeneity across firms, with low-risk firms having a shallow slope of the leverage-spread schedule and high-risk firms having a steeper schedule. We would also like to extend the BGG framework to include some form of multi-period debt contract 1to address the issue of the relationship between leverage and degree of idiosyncratic risk outlined at the end of the previous section. Furthermore, we plan to use perturbation methods to obtain second-order approximation of the model around the steady state, characterize the optimal monetary policy, and compare the welfare performance of alternative simple rules.

Finally, it would be interesting to extend our empirical analysis to the open economy framework, considering different measures of leverage and spread for emerging markets. 


\section{References}

Aghion, P., P. Bacchetta, And A. Banerjee (2000): "A Simple Model of Monetary Policy and Currency Crisis," European Economic Review, Papers and Proceedings, 44, 728-738.

Alderson, M. J., And B. L. Betker (1995): "Liquidation Costs and Capital Structure," Journal of Financial Economics, 39, 45-69.

Altman, E. I. (1984): "A Further Empirical Investigation of the Bankruptcy Cost Question," Journal of Finance, 39, 1067-1089.

Bernanke, B. S. (2000): Essays on the Great Depression. Princeton University Press, Princeton, NJ.

Bernanke, B. S., And J. Y. Campbell (1988): "Is There a Corporate Debt Crisis?," Brookings Papers on Economic Activity, 1, 83-125.

Bernanke, B. S., And M. Gertler (1989): "Agency Costs, Net Worth, and Business Fluctuations," American Economic Review, 79, 14-31.

- (1995): "Inside the Black Box: The Credit Channel of Monetary Policy Transmission," Journal of Economic Perspectives, 9, 27-48.

Bernanke, B. S., M. Gertler, and S. Gilchrist (1999): "The Financial Accelerator in a Quantitative Business Cycle Framework," in The Handbook of Macroeconomics, ed. by J. Taylor, and M. Woodford, pp. 1341-1393. Elsevier Science B.V., Amsterdam, The Netherlands.

Caballero, R. J., and A. Krishnamurthy (2000): "Emerging Market Crisis: An Asset Markets Perspective," Mimeo, Dept. of Economics, MIT.

Carlstrom, C. T., and T. S. Fuerst (1997): "Agency Costs, Net Worth, and Business Cycle Fluctuations: A Computable General Equilibrium Analysis," American Economic Review, 87, 893-910.

Cespedes, L. F., R. Chang, and A. Velasco (2000): "Balance Sheets and Exchange Rate Policy," NBER Working Paper No. 7840.

Choi, Y., And J. PARK (2002): "An Improved Approach to Calculate the Yield and Duration of a Bond Portfolio," Journal of Applied Finance, Fall/Winter, 55-60.

Christiano, L. J., R. Motto, and M. Rostagno (2004): "The Great Depression and the Friedman-Schwartz Hypothesis," NBER Working Paper No. 10255. 
Cooley, T. F., R. Marimon, and V. Quadrini (2004): "Aggregate Consequences of Limited Contract Enforceability," Forthcoming, Journal of Political Economy.

Cooper, I. A., and S. A. Davydenko (2002): "Using Yield Spreads to Estimate Expected Returns on Debt and Equity," Mimeo, London Business School.

Crosbie, P. J., And J. R. Bohn (2003): "Modeling Default Risk," Research Report, Moody's $\mid \mathrm{K} \cdot \mathrm{M} \cdot \mathrm{V}$ Corporation.

Cummins, J. G., K. A. Hassett, and S. D. Oliner (1999): "Investment Behavior, Observable Expectations, and Internal Funds," Finance and Economics Discussion Series Paper No. 27, Federal Reserve Board.

Delianedis, G., And R. Geske (2001): "The Components of Corporate Credit Spreads: Default, Recovery, Tax, Jumps, Liquidity, and Market Factors," Mimeo, UCLA Anderson Graduate School of Management.

Elton, E. J., M. J. Gruber, D. Agrawal, and C. Mann (2001): "Explaining the Rate Spread on Corporate Bonds," Journal of Finance, 56, 247-277.

Ericsson, J., And J. Reneby (1999): "A Note on Contingent Claims Pricing with Non-Traded Assets," Working Paper No. 314, Stockholm School of Economics.

Fisher, I. (1933): "The Debt-Deflation Theory of Great Depression," Econometrica, $1,337-357$.

Gale, D., and M. Hellwig (1985): "Incentive-Compatible Debt Contracts: The One-Period Problem," Review of Economic Studies, 52, 647-663.

Gertler, M., S. Gilchrist, and F. M. Natalucci (2003): "External Constraints on Monetary Policy and the Financial Accelerator," NBER Working Paper No. 10128.

Hubbard, R. G. (1998): "Capital Market Imperfections and Investment," Journal of Economic Literature, 36, 193-225.

Kaplan, S. N., and L. Zingales (1997): "Do Investment-Cashflow Sensitivities Provide a Useful Measure of Financing Constraints?," Quarterly Journal of Economics, 112, 169-215.

Kiyotaki, N., And J. H. Moore (1997): "Credit Cycles," Journal of Political Economy, 105, 211-248.

Krugman, P. (1999): "Analytical Afterthoughts on the Asian Crisis," Mimeo. 
Merton, R. C. (1973): "A Rational Theory of Option Pricing," Bell Journal of Economics and Management Science, 4, 141-183.

(1974): "On the Pricing of Corporate Debt: The Risk Structure of Interest Rates," Journal of Finance, 29, 449-470.

Modigliani, F., And M. H. Miller (1958): "The Cost of Capital, Corporation Finance, and the Theory of Investment," American Economic Review, 38, 261-297.

Smith, D. C., And P. Strömberg (2003): "Maximizing the Value of Distressed Assets: Bankruptcy Law and the Efficient Reorganization of Firms," Mimeo, Federal Reserve Board.

Svensson, L. E. O. (1994): "Estimating and Interpreting Forward Interest Rates: Sweden 1992-1994," IMF Working Paper No. 94-114.

Townsend, R. M. (1979): "Optimal Contracts and Competitive Markets with Costly State Verification," Journal of Economic Theory, 21, 265-293.

Warga, A. D. (1991): "A Fixed Income Database," Mimeo, University of Houston.

White, H. (1980): "A Heteroscedasticity-Consistent Covariance Matrix Estimator and a Direct Test for Heteroscedasticity," Econometrica, 48, 817-838. 